\title{
Assessment of shop floor layouts in the context of process plans with alternatives
}

\author{
Claudio Decker Juniora* (D), João Carlos Espíndola Ferreira ${ }^{\mathrm{b}}$ (D), Elisa Henning ${ }^{\mathrm{c}}$ (D), \\ Carla Roberta Pereira ${ }^{a}$ \\ aUniversidade do Estado de Santa Catarina, Departamento de Engenharia de Produção, Florianopolis, SC, Brasil \\ bUniversidade Federal de Santa Catarina, Engenharia Mecânica, Florianópolis, SC, Brasil \\ 'Universidade do Estado de Santa Catarina, Departamento de Matemática, Joinville, SC, Brasil \\ *claudiodecker@gmail.com
}

\begin{abstract}
Paper aims: The paper seeks to compare the performance of three layouts in a make to order (MT0) production system with high product variability.

Originality: No previous work sought to compare job shop, cellular and virtual cell layouts in an MTO system with high product variability, with just 21 resources, a low amount. The analysis considered models with the same capacities and demand for the three layouts.

Research method: The complete factorial design and ANOVA were used with simulation. The main effects plots of the control factors for response variables were obtained (e.g. throughput, lead time, and resource utilization).

Main findings: The virtual cell layout had results similar to the job shop, but achieved better outcomes compared with the traditional cell.

Implications for theory and practice: The knowledge gap regarding virtual cells signals the importance of this topic, as well as the possibilities not yet investigated about it in manufacturing companies.
\end{abstract}

\section{Keywords}

Virtual cells. Process plans with alternatives. Layouts. Simulation. Design of experiments.

How to cite this article: Decker Junior, C. D., Ferreira, J. C. E., Henning, E. \& Pereira, C. R.. (2019). Assessment of shop floor layouts in the context of process plans with alternatives. Production, 29, e20180078. https://doi.org/10.1590/01036513.20180078.

Received: Sept. 4, 2018; Accepted: Dec. 14, 2018.

\section{Introduction}

According to Andersen et al. (2017), in today's globalized production environment, changes are inevitable, and manufacturers must take advantage of either new technologies, changes in products or manufacturing processes. Paydar \& Saidi-Mehrabad (2014) point out that for a company to survive, it is very important to meet the needs of customers, who demand products with high quality and lower prices (Arkat \& Ghahve, 2014; Garza-Reyes et al., 2016; Paydar \& Saidi-mehrabad, 2017). Continuous improvement of processes and products are key to have loyal customers and corporate survival (Mclean \& Antony, 2017).

Andrade \& Fernandes (2018) point out the importance of integrating the stages of the production process through the interoperable integration since its planning. In this context, Mahdavi et al. (2011) mention that the use of process plans with pre-established alternatives can be advantageous, since a previously selected alternative resource can be included during the process plan elaboration. The presence of pre-planned alternatives can provide more flexibility in decision making (Ferreira \& Wysk, 2001a, 2001b; Phanden et al., 2013). 
In turn, Khilwani et al. (2011), Silva \& Rentes (2012), Defersha \& Hodiya (2017) and Sieckmann et al. (2018) show that the appropriate choice of the shop floor layout is essential to enable and increase the competitiveness of a company in today's globalized economy.

In the context of a cellular manufacturing system, its advantages are: smaller batch sizes, reduction of work in process (WIP), and reduction of flow time (Ekren \& Ornek, 2008; Javadi et al., 2013; Alhourani, 2015). Ferreira \& Reaes (2013) emphasize that both the reduction of flow and setup times, as well as the flexibility of the part routes, are very important characteristics for the viability of the business. Seeking to combine these two characteristics, the concept of virtual cells arises.

According to Mclean et al. (1982), a virtual cell is composed of machines from different departments that are associated logically during a certain time interval. Although physically arranged as in the job shop arrangement, the layout works as a traditional manufacturing cell. A virtual cell is not identifiable by a physical cluster, but by data files and processes within a production controller (Rheault et al., 1995).

Dakov et al. (2010) and Rabbani et al. (2018) point out that VCMS (Virtual Cell Manufacturing Systems) were a first attempt at practical use for the concept of virtual cells. They mention as an important advantage of virtual cells over other layouts the almost unlimited adaptability to different production volumes without reducing the efficiency and effectiveness of the system.

Paydar \& Saidi-mehrabad (2017) cite as an advantage of virtual cells the fact that the cellular arrangement occurs virtually, which is appropriate in the case of significant variations in the demand of parts, not being necessary the physical rearrangement of machines.

Ramachandran \& Prasad (2014) cite the better performance of the virtual cell layout in different scenarios. It is worth mentioning the swiftness with which the system responds to demand changes.

For the analysis of different types of layouts and their effects on the production systems, different situations can be simulated. For Freitas Filho (2008), simulation allows to understand the dynamics of a system, to analyze and to predict the effects of changes. Watanapa \& Wiyaratn (2018) emphasize the importance of simulation, since it enables considering different scenarios to analyze the same problem. Mesquita et al. (2017) point out that the use of simulation assists in the anticipation of analyzes of real problems found in companies.

In turn, Kleijnen et al. (2005) state that design of experiments (DOE) assists the analysis of simulation results. In addition, DOE avoids the trial-and-error technique for finding solutions (Montevechi et al., 2007).

Based on the standard adopted by Mello (2005), who did not consider the type of layout, he attempted to show that the use of alternatives provides advantages to manufacturing systems. Reaes (2008) presented a more comprehensive research, concluding that the virtual cellular layout performs better than traditional job shop and cellular layouts. However, Reaes (2008) did not consider in detail the design of products, limiting to 50 different types of parts. The parts in the present work were composed randomly, that is, a universe of features was stipulated, from which an infinite number of different products could be generated, trying to stimulate a scenario as close as possible to reality, where the market demands more and more flexibility, variety of product mix and shorter life cycles of products.

With regard to relevance, the results of the virtual cellular layout with a small number of resources, 21 in total, are highlighted, complementing the results found by Reaes (2008), with 50 features, showing the applicability of the virtual cellular layout.

The choice of these three layouts was due to the virtual cellular layout linking the positive characteristics of both the job shop and the cellular layouts.

In this scenario, the objective of this paper is to compare the job shop, virtual cell and traditional cell layouts, identifying for which conditions each layout achieves better performance for different response variables.

\section{Brief literature survey}

This section contains a brief literature review of works that deal with manufacturing layouts, and process planning within different layouts.

\subsection{Layouts}

A layout establishes the physical location of the transforming resources, i.e., the facilities, machines, equipment, operators, etc. (Silva \& Rentes, 2012; Wang et al., 2015; Cheng Ying et al., 2016). In addition, it establishes how transformed resources (i.e., raw materials, materials, parts, etc.) should flow along operations (Wang et al., 2015; Cheng Ying et al., 2016). According to Silva \& Rentes (2012), the physical location has impacts in several 
aspects on the shop floor, and Khilwani et al. (2011) point out that the type of layout should focus on the flow of materials, seeking to increase production efficiency and reduce costs. The provision of transforming resources in a facility directly affects production costs and throughput (Murthy et al., 2016). An adequate allocation of resources contributes significantly to the increase of efficiency of the operations and reduces transportation costs (Drira et al., 2007; Murthy et al., 2016).

Virtual cells operate virtually as cells from a logical point of view, that is, resources are dedicated to manufacture a family of parts, similarly to traditional cells. At the moment when family of parts is completely manufactured, the virtual cell formation is undone logically, and each individual resource being able to re-group with others constitute a new virtual cell (Suresh \& Slomp, 2005; Sieckmann et al., 2018).

Figure 1 shows an example of virtual cell layout, where three virtual cells are temporarily formed to manufacture one production order each, with the geometric figures representing different types of machines present on the shop floor.

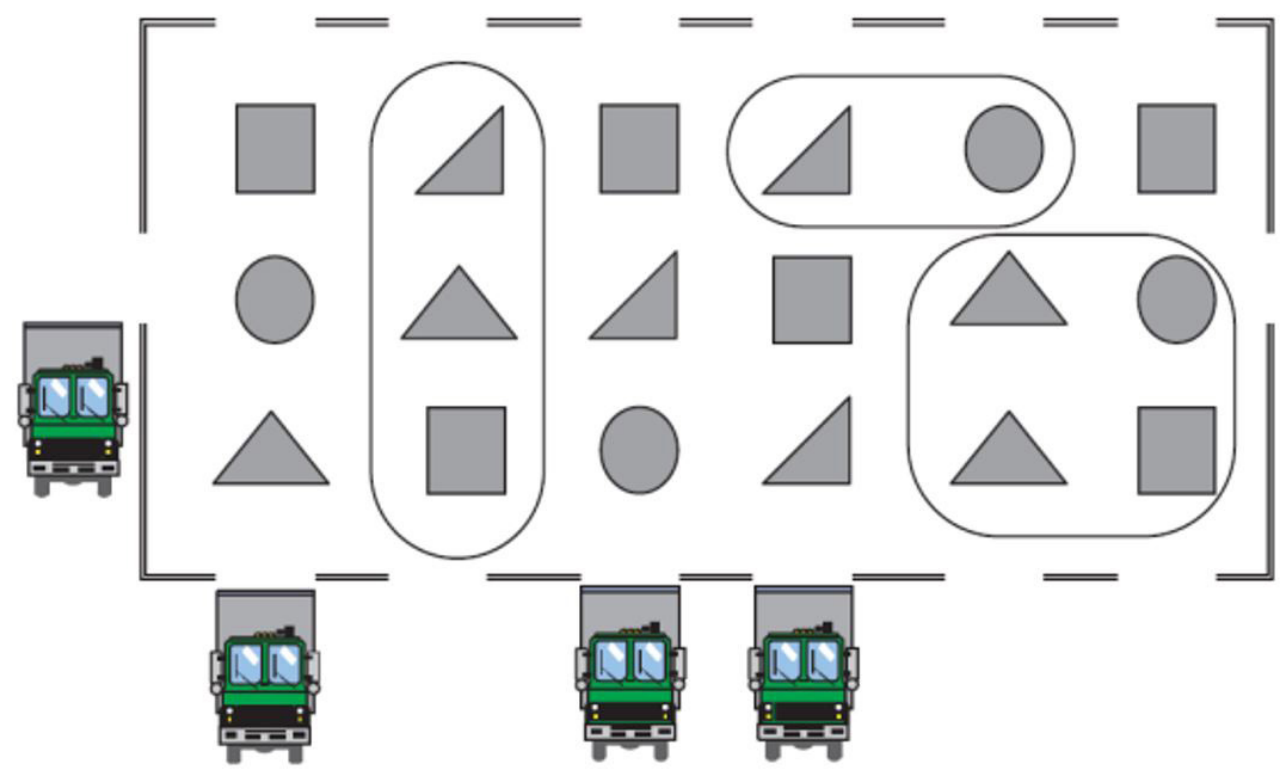

Figure 1. An example of a virtual cell layout.

Source: Drolet et al. (2008).

Arkat \& Ghahve (2014) point out that the temporary virtual arrangement is often adjusted, being changed according to the characteristics of the batches of parts to be manufactured by the production control and available resources.

It is noteworthy that in the literature there are several approaches regarding the layout theme, for which a simplified Systematic Literature Review (SLR) was developed based on the guidelines of Tranfield et al. (2003, 2004). Karl et al. (2018) cites the importance of systematic literature review as a way to build approaches from a large number of studies, without neglecting relevant research. Table 1 presents the 5 steps that describe the literature review protocol (SLR) from Tranfield et al. (2003, 2004) and Karl et al. (2018).

Table 1. SLR protocol.

\begin{tabular}{ll}
\hline \multicolumn{1}{c}{ Step } & \\
\hline Question formulation & - develop review questions to achieve the aim of the study \\
& - develop search requires; \\
Location studies & - search on Scopus, ScienceDirect and Scielo databases; \\
& Search in 35-year period (Jan/1982 - Dec/2017) \\
& - 1st selection: title; \\
Study selection and evaluation & - 2nd selection: abstract and keywords; \\
& - 3rd selection introduction, conclusion and searching for the paper's content. \\
& - carefully read papers; \\
Analysis and synteshis & - use Excel spreadsheet to code and organize the content based on what is intended to answer from the \\
& research questions; \\
Result presentation & - answer the review questions based on what is known in the literature.
\end{tabular}


Given the purpose of the article in comparing the different layouts, two Review Questions (RQs) are stated: RQ1 - What types of existing and used layouts?

RQ2 - What are the performance comparisons of different layouts?

The first question (RQ1) surrounds all types of layouts that have already been enunciated in the literature since the creation of the concept of virtual cellular layout in 1982. The second question (RQ2) tends to contemplate the possible comparisons of these different layouts and how performance of each layout in these assessments.

In the next step it is necessary to determine the search queries from the two questions proposed. Tests were made before determining the final search. The searches were carried out in the bases ScienceDirect and Scopus, including the Brazilian base Scielo. The choices of the bases were given by the access of the authors. Table 2 lists the keywords used to develop the search queries.

Table 2. Search parameters.

\begin{tabular}{|c|c|c|}
\hline Constructs & Keywords & Search queries \\
\hline Layouts types & $\begin{array}{l}\text { Positional; Functional; Jobshop; Process; Cell; Cellular; Virtual } \\
\text { cellular; Virtual cellular manufacturing (VCM); Virtual cellular } \\
\text { manufacturing system (VCMS) }\end{array}$ & $\begin{array}{l}\text { layout* W/3 (positional OR functional OR job* } \\
\text { OR process OR cell* OR virtual cell* OR VCM } \\
\text { OR VCMS) }\end{array}$ \\
\hline $\begin{array}{l}\text { Layouts performance } \\
\text { evaluation }\end{array}$ & $\begin{array}{l}\text { Analysis; Configuration; Modelling; Model; Performance; } \\
\text { simulation }\end{array}$ & $\begin{array}{l}\text { layout* W/3 (analys* OR configur* OR model* } \\
\text { OR performance OR simula*) }\end{array}$ \\
\hline $\begin{array}{l}\text { Layouts types and layouts } \\
\text { performance evaluation }\end{array}$ & $\begin{array}{l}\text { Positional; Functional; Jobshop; Process; Cell; Cellular; Virtual } \\
\text { cellular; Virtual cellular manufacturing (VCM); Virtual cellular } \\
\text { manufacturing system (VCMS); Analysis; Configuration; } \\
\text { Modelling; Model; Performance; simulation }\end{array}$ & $\begin{array}{l}\text { (layout }^{*} \text { W/3 (positional OR functional OR job* } \\
\text { OR process OR cell* OR virtual cell* OR VCM OR } \\
\text { VCMS)AND layout* W/3 (analys* OR configur* } \\
\text { OR model* }{ }^{*} \text { OR performance OR simula*)) }\end{array}$ \\
\hline
\end{tabular}

In the study selection and evaluation stage, a period of 35 years was considered (Jan/1982 - Dec/2017), considering that the beginning of publications regarding the virtual cellular layout began in 1982 (Mclean et al., 1982). In the first search, 3,584 articles were identified, and 396 articles were selected after evaluating their respective titles, which are related to the term layout, in addition to some reference to performance, modeling, configuration, design or analysis comparison. From these 396 articles, we verified the keywords and the abstracts, which resulted in 31 articles that were read the introductions and conclusions.

According to Thomé et al. (2016), several alternative approaches can be used to systematically analyze and synthesize the literature review. The analysis of these 31 articles was done using MS Excel to tabulate the information, organize and analyze the data.

The final step intends to present succinctly the results found from the systematic literature review (SLR). Table 3 summarizes and aims to answer the two questions raised above (RQ1 and RQ2) about the types of layouts and the forms of performance of these layouts. It is convenient to emphasize that none of these articles compare the three layouts proposed in this study. Most of the studies found focus on cell layouts (13 articles), and jobshop (7 articles). Only 3 articles deal with virtual cellular layout within the stipulated comparative context. Regarding the methods of comparison, it is noteworthy that 12 articles dealt with the comparison of layouts, besides 9 articles that deal with the formation of cells. About the simulation tool, 7 out of 31 articles used it. However, most of the articles used together, mathematical models, Taguchi, genetic algorithm, optimization and multi-criteria.

Among the articles analyzed, some works have brought interesting contributions. Mahdavi et al. (2011) present an approach based on fuzzy programming to solve a multi-objective mathematical model of the cell formation problem and production planning in a dynamic virtual cell manufacturing system. The authors point out that in a dynamic environment the product mix and demand variation directly affect production planning.

Paydar \& Saidi-Mehrabad (2014) developed a mathematical model of optimization using virtual cells to integrate all stages, from acquisition, planning, production and distribution.

Deep \& Singh (2016) presented an integrated mathematical model for the design of cellular manufacturing systems including cell formation, routing process and system reconfiguration. The model presents flexibility in planning considering capacity, in addition to using the algorithm based on optimal sequencing. The results showed that the coexistence of multiple resources provides greater flexibility.

In the context of Virtual Cell Manufacturing Systems (VCMS), different techniques have been developed to solve problems of virtual cell formation (Hamedi et al., 2012a; Paydar \& Saidi-mehrabad, 2017).

Table 4 lists some works that deal with the different types of layout, the researches developed and the results achieved. It is observed that the authors listed in table 1 developed mathematical models for the formation of virtual cells, using the most varied techniques. It is worth highlighting the paper by Ramachandran \& Prasad 
Table 3. Layout Types.

\begin{tabular}{|c|c|c|c|c|c|c|c|c|c|c|c|c|c|c|c|c|c|c|c|c|}
\hline \multirow[b]{2}{*}{ Authors } & \multicolumn{10}{|c|}{ Layout types } & \multicolumn{10}{|c|}{ Layout performance } \\
\hline & 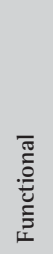 & $\begin{array}{l}\frac{0}{0} \\
\frac{1}{n} \\
\stackrel{0}{0}\end{array}$ & $\frac{\frac{\pi}{\pi}}{\bar{\Xi}}$ & 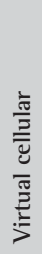 & $\sum_{>}^{n}$ & $\sum_{>}$ & 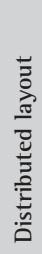 & 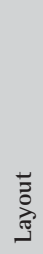 & 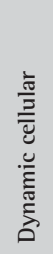 & 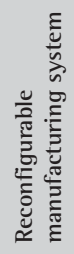 & 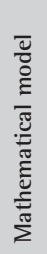 & 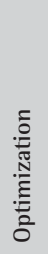 & 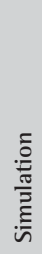 & 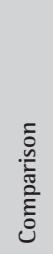 & 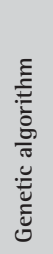 & 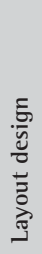 & 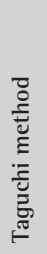 & 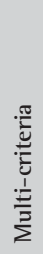 & 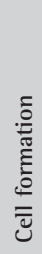 & 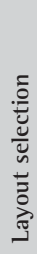 \\
\hline Shafer \& Charnes (1993) & $\mathrm{x}$ & & $x$ & & & & & & & & & & $\mathrm{x}$ & & & & & & & \\
\hline Morris \& Tersine (1994) & & & $x$ & & & & & & & & & & $\mathrm{x}$ & $x$ & & & & & & \\
\hline Ertay (1998) & & & $\mathrm{x}$ & & & & & & & & & & $\mathrm{x}$ & $\mathrm{x}$ & & & & & & \\
\hline Agarwal \& Sarkis (2001) & $\mathrm{x}$ & & $x$ & & & & & & & & & & & $\mathrm{x}$ & & & & & & \\
\hline $\begin{array}{l}\text { Bazargan-Cart \& Nahavandi } \\
\text { (2001) }\end{array}$ & & & $\mathrm{x}$ & & & & & & & & & & & & & & & $x$ & & \\
\hline Assad et al (2003) & $\mathrm{x}$ & & $\mathrm{x}$ & & & & & & & & & & $\mathrm{x}$ & $x$ & & & & & & \\
\hline Drolet et al. (2008) & & $\mathrm{x}$ & $\mathrm{x}$ & & & & & & $x$ & & & & & $x$ & & & & & & \\
\hline Rezazadeh et al. (2009) & & & & & & & & & $x$ & & & $\mathrm{x}$ & & & & & & & & \\
\hline Jayachitra et al. (2010) & & & & $x$ & & & & & & & & & & & & & & & $x$ & \\
\hline Jerbi et al. (2010) & $\mathrm{x}$ & & $\mathrm{x}$ & & & & & & & & & & & & & & $\mathrm{x}$ & & & \\
\hline Kamaruddin et al. (2011) & $\mathrm{x}$ & $\mathrm{x}$ & $x$ & & & & & & & & & & $x$ & $x$ & & & & & & \\
\hline Rajapakshe et al. (2011) & & & $\mathrm{x}$ & & & & & & & & & & & $x$ & & & & & & \\
\hline Jayachitra \& Prasad (2011) & $\mathrm{x}$ & & & $\mathrm{x}$ & $\mathrm{x}$ & $\mathrm{x}$ & & & & & & & & $x$ & & & & & & \\
\hline Mahdavi et al. (2011) & & & & & & & & & $\mathrm{x}$ & & & & & & & & & & $x$ & \\
\hline Khilwani et al. (2011) & & & & & $\mathrm{x}$ & & & & & & & & & & & & & & $x$ & \\
\hline Hamedi et al., 2012a & & & & & $x$ & & & & & & & & & & & & & & $x$ & \\
\hline Hamedi et al. (2012b) & & & & & $x$ & & & & & & & & & $x$ & & & & & $x$ & \\
\hline Hamedi et al. (2012c) & & & & & $\mathrm{x}$ & & & & & & & & & $\mathrm{x}$ & & & & & $\mathrm{x}$ & \\
\hline Khaksar-Haghani et al. (2012) & & & & & $\mathrm{x}$ & & & & & & & & & & $\mathrm{x}$ & & & & & \\
\hline Dias et al. (2014) & & & & & & & & $\mathrm{x}$ & & & & $\mathrm{x}$ & & & & & & & & \\
\hline Medina-Herrera et al. (2014) & & & & & & & & $x$ & & & $\mathrm{x}$ & & & & & & & & & \\
\hline Ramachandran \& Prasad (2014) & & & $\mathrm{x}$ & $\mathrm{x}$ & & & & & & & & & & $x$ & & & & & & $\mathrm{x}$ \\
\hline Mar-Ortiz et al. (2015) & & & $\mathrm{x}$ & & & & & & & & & & & $\mathrm{x}$ & & & & & & \\
\hline Shafigh et al. (2015) & & & & & & & $\mathrm{x}$ & & & & $x$ & & & & & & & & & \\
\hline Paydar \& Saidi-Mehrabad (2014) & & & $\mathrm{x}$ & & & & & & $\mathrm{x}$ & & $\mathrm{x}$ & & & & & & & & $x$ & \\
\hline Hamedi \& Esmaeilian (2015) & $x$ & & & & $x$ & & $\mathrm{x}$ & & & & & $\mathrm{x}$ & & & & & & & & \\
\hline Gupta et al. (2015) & & & & & & & & & & $\mathrm{x}$ & & & & & & & & & & $x$ \\
\hline Sakhaii et al. (2016) & & & & & & & & & $x$ & & & $\mathrm{x}$ & & & & & & & & \\
\hline Deep \& Singh (2016) & & & & & & & & & $x$ & & & & & & & $\mathrm{x}$ & & & $x$ & \\
\hline Paydar \& Saidi-Mehrabad (2017) & & & & & & & & & $x$ & & & & & & $x$ & & & & $x$ & \\
\hline Rabbani et al. (2018) & & & & & & & & & $\mathrm{x}$ & & & & $\mathrm{x}$ & & & & & & & \\
\hline
\end{tabular}

(2014), which performs a comparison of layouts. Among the differences of the Ramachandran \& Prasad (2014) proposal for the presented research is the design of experiments that aided in the identification of the main control factors that affect the results. In addition, process plans with alternatives were used in the research.

\subsection{Process planning in the context of shop floor layouts}

The task of process planning involves the interpretation and conversion of the product design for its manufacture (Deja \& Siemiatkowski, 2012; Andrade \& Fernandes, 2018; Haddou Benderbal et al., 2017; Kongchuenjai \& Prombanpong, 2017).

According to Ferreira \& Wysk (2001a,b), there is often more than one alternative resource to perform an operation, and consequently to manufacture a part. Colosimo et al. (2000) point out that, normally, the elaboration of process plans does not consider alternative resources, although Zattar et al. (2010) highlight the importance of the results achieved with the use of alternative plans. 
Table 4. Some publications about different layouts and their results.

\begin{tabular}{|c|c|}
\hline Author & Description \\
\hline $\begin{array}{l}\text { Rezazadeh et al. } \\
\text { (2009) }\end{array}$ & $\begin{array}{l}\text { Contains a mixed-integer programming model to design VMC } \\
\text { in a dynamic environment. They incorporated the information } \\
\text { about production planning, system reconfiguration and } \\
\text { workforce requirement. It attempts to minimize the total sum } \\
\text { of the following costs: manufacturing, material handling, } \\
\text { subcontracting, inventory holding, internal production and } \\
\text { cross-training for workers over the planning horizon. A particle } \\
\text { swarm optimization algorithm was used to solve the problem. }\end{array}$ \\
\hline $\begin{array}{l}\text { Jayachitra et al. } \\
\text { (2010) }\end{array}$ & $\begin{array}{l}\text { Inspired by principles and advantages of group technology } \\
\text { (GT), part family formation for a virtual Cell Manufacturing } \\
\text { System (VCMS) using fuzzy logic is performed for dynamic } \\
\text { and uncertain conditions. A mathematical binary-integer } \\
\text { programming model is proposed to minimize the following: } \\
\text { fixed machine costs, variable costs of all machines, and the } \\
\text { logical group movement costs. }\end{array}$ \\
\hline
\end{tabular}

Khilwani et al. Design virtual cells that maximize similarity and minimize lead (2011) time. Emphasis on machine sharing.

Hamedi et al. Review on virtual cell manufacturing systems (VCMS). (2012a) Techniques to solve problems of formation of virtual cells.

Hamedi et al. Virtual cell formation using a nonlinear programming model. (2012b)

Hamedi et al. (2012c)

Multiobjective mathematical model based on elements and resources. They validate the model through a numerical example taken from the literature.

A comparative study is done between the layouts via

Ramachandran \& simulation. Operational parameters considered were

Prasad (2014) throughput, machine utilization, average work-in-process and average flow time.

Esmaeilian (2015) shop and distributed layouts. A multiobjective function with a Tabu Search algorithm was used.

A configuration selection problem was considered to determine the optimal configuration with respect to the set Gupta et al of performance criteria. Due to simultaneous consideration of several criteria in the problem, entropy-based analytical hierarchy process (AHP) was adopted for the analysis. To overcome the subjectivity in the decision maker's judgment, the results were analyzed for sensitivity.

New multi-objective mathematical model for dynamic cellular manufacturing system (DCMS) is provided with consideration of machine reliability and alternative process routes. Two

Rabbani et al. (2018) proposed for solving the problem. Also, a simple way to code the problem was introduced. To validate the proposed model, a small-sized problem was solved with GAMS software.
Advantages of their model: simultaneous consideration of dynamic system configuration, operation sequence, alternative process plans for part types, machine and worker capacity, workload balancing, cell size limit and batch splitting.

Very good results were obtained when comparing the proposed fuzzy logic method with a simulated annealing algorithm and a rank order clustering algorithm.

The benefits of using virtual cells increase with the greater variety of machines required to process a particular part. They point to the need to study virtual cells more deeply.

They use mathematical programming to get the best solutions to the problem of virtual cell formation.

Better performance when compared with traditional cell systems.

Companies can take advantage of virtual cell manufacturing systems. Especially those that work with a very unpredictable production environment.

In most of the proposed scenarios the virtual cell layout presented better performance.

The distributed layout was more efficient than the job shop in terms of the distance travelled, but with regard to capacity utilization there is no significant difference between these layouts.

The proposed method provides a system design analytical tool and can be easily adopted by the system designer or industrial engineering.

As expected, due to the discrete nature of the problem, the results showed that the NSGA-11 could discover more Pareto solutions than MOPSO and the solutions obtained by NSGA-11 had more diversity than MOPSO. Also, it had more quality than MOPSO on average, but Pareto solution of algorithm MOPSO had more uniformity.

Deja \& Siemiatkowski (2010) point out that the availability of process plans with alternatives is an important factor to integrate product design, process planning and production scheduling.

Fung et al. (2006) mention that the capacity of each machine and the operations that it can be perform are well defined. However, some operations can be performed on more than one machine, which results in the dynamic aspect of process planning.

Lv et al. (2014) point out that studies of virtual manufacturing cells focus, in addition to layout, algorithms for virtual cell design, process planning, and process planning models.

Arkat \& Ghahve (2014) identified that most researches assumed that set-up times established in process plans are independent of production sequencing, thus being neglected or included in processing times, which simplifies the analysis but affects the outcome of the solution.

Dakov et al. (2010) emphasize the use of virtual cell layout in conjunction with process planning. They developed a theoretical model for the cellular arrangement based on workstations and an algorithm that elaborates the process planning simultaneously. 
Morales \& Ronconi (2015) considered mathematical models to solve the production scheduling problem of the classic job shop model, evaluating six different formulations and solve 45 problems from the literature. They consider the static deterministic case, where the processing time of each operation and the sequence of operations for each task are known and not variant, and all machines and tasks are available at the beginning of processing.

Fuchigami et al. (2015) evaluated 12 methods to minimize the total production sequencing time (makespan). The setup times were considered and their emphasis was on flexible flow lines.

There is a gap in the literature in the effective comparison between different types of layouts, in such a way that it can help the shop floor professional to specify the best layout for each scenario. In this context, this study seeks to analyze and compare the performance of three different types of layout through experiments based on simulations under conditions of a make-to-order (MTO) manufacturing system (i.e. a system that produces parts to satisfy orders with specific due dates). The method used in this work is presented in section 3.

\section{Description of the proposed method}

This section contains a description of the proposed method for the evaluation and comparison of three different manufacturing layouts using simulation and design of experiments.

\subsection{Design of experiments}

According to Sanchez (2008), experimental design employs factors, which are independent variables, to test the impact on the outputs of the experiments, which are the response variables. As stated by Montgomery (2012), this technique is useful to verify if a given factor influences, or not, the response of a system.

For Gomes (2010) and Costa (2010), an experimental problem can be supported by the design of experiments and the statistical analysis of the data. There are several types of data collection strategies for DOE, and one of them is the complete factorial design.

Table 5 shows the control factors used in this paper.

Table 5. Control factors used in the proposed method.

\begin{tabular}{|c|c|c|c|}
\hline Factor & Description & Level & Value \\
\hline \multirow[t]{2}{*}{ Features per part } & Quantity of features in the part & Low & 1 to 3 features per part \\
\hline & & High & 7 to 10 features per part \\
\hline \multirow[t]{2}{*}{ Duplicated Features } & Quantity of duplications of the same feature in each part & Low & 1 to 3 features \\
\hline & & High & 7 to 10 features \\
\hline \multirow[t]{2}{*}{ Batch Size } & Quantity of parts in each batch & Low & 10 to 50 parts \\
\hline & & High & 200 to 500 parts \\
\hline \multirow[t]{2}{*}{ Type of Demand } & Type of demand which will be applied to the system & Low & Random \\
\hline & & High & Controlled \\
\hline \multirow[t]{2}{*}{ Type of Plan } & Process plan used in simulation (with or without alternatives) & Low & Plan With alternatives \\
\hline & & High & Plan Without alternatives \\
\hline \multirow[t]{2}{*}{ Simulated Batches } & Total quantity of simulated batches in each replication & Low & 50 batches \\
\hline & & High & 200 batches \\
\hline \multirow[t]{2}{*}{ Arrival time } & Arrival time from the current batch to the next batch & Low & $5 \%$ to $10 \%$ of processing time \\
\hline & & High & $20 \%$ to $30 \%$ of processing time \\
\hline \multirow[t]{2}{*}{ Maintenance } & Maintenance concepts applied in the machines & Low & With maintenance \\
\hline & & High & Without maintenance \\
\hline
\end{tabular}

The response variables that are considered: throughput (parts/hour), work in process (parts), resource utilization (\%), final time (hours), total waiting time (hours) and lead time (hours).

In order to perform the analysis, three types of layout are considered: the job shop layout, the traditional cell layout and the virtual cell layout. Both process plans with alternatives as well as conventional plans (without alternatives) are considered. In the case of selecting an alternative operation, a penalty of $40 \%$ in the machining time is applied. An explanation for this penalty is that, if a hole needs to be made in a part, it may be performed in a milling machine or a drilling machine. Usually a milling machine will be chosen due to its versatility when 
compared with the drilling machine. But since the drilling machine can also be used to make the hole, it is included as an alternative in the process plan, but a less desirable one.

In order to reduce errors inherent to the variability in the execution of the simulation, 10 replications were performed for each combination of factors, that is, each experiment was replicated 10 times. Also, a full factorial design was used, meaning that all possible combinations were performed.

According to table 2, there are eight control factors and, since only two levels were chosen in each factor (high and low), $2^{\wedge} 8=256$ experiments were tested. Since for each experiment ten simulations were run, a total of 2,560 experiments were performed. This set of 2,560 experiments was applied to each of the three different layouts (job shop, traditional cell and virtual cell), totaling 7,680 experiments. The total simulation times were one of the control factors of the experiment, and the warm-up time was $1 \mathrm{~h}$. That is, the first hour of each simulation was excluded from the statistical analysis.

\subsection{Simulation model}

With regard to the simulation model, this task was divided into two stages. In the first stage, the production orders of the batches of the parts are carried out, in which the following activities are performed: generation of the parts' features, specification of the quantity of duplicate features, specification of the batch size, specification of the demand type, generation of the machining sequence, and calculation of the machining times. Chin (2013) emphasizes the importance of batch size analysis, evaluating different strategies of batch sizes applied to virtual cells, seeking to reduce manufacturing times.

In the second stage, the system is simulated using the Arena software. The results obtained are stored in a spreadsheet for later statistical analysis. The flowchart shown in Figure 2 illustrates the stages and activities of the proposed method.

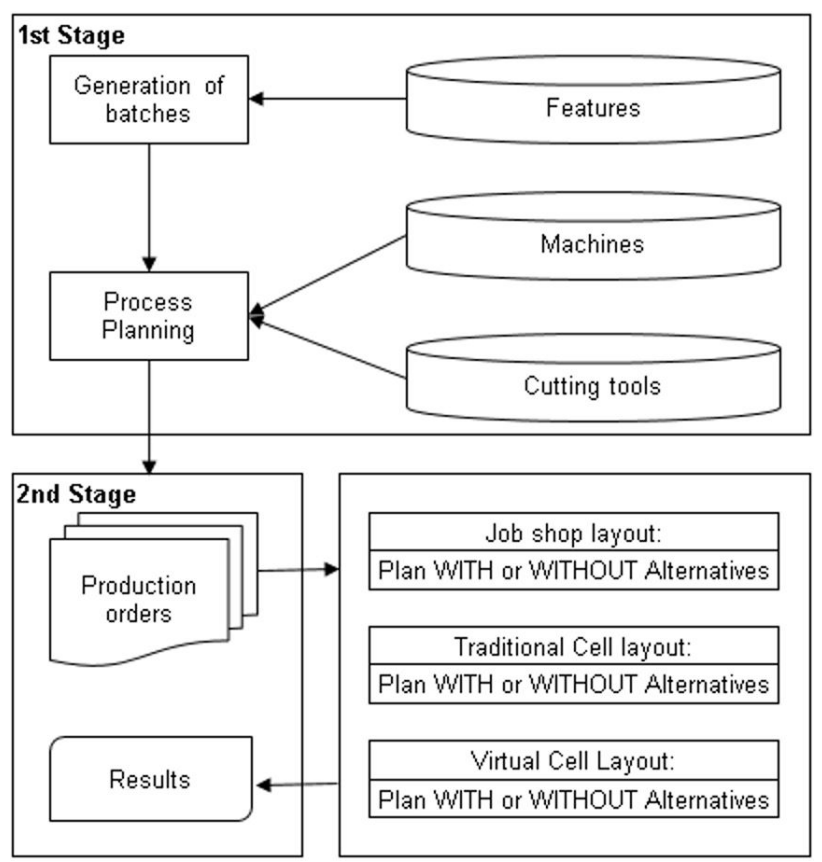

Figure 2. Stages and activities for performing the simulation.

\section{Application of the proposed method}

Three different systems were modeled to evaluate the response variables according to the control factors. For all three models, a make to order (MT0) production system was considered. A system for the job shop layout was modeled, another for the traditional cellular layout and a third for the virtual cell layout.

In the first stage of the simulation model, the MS Excel random tool was used to generate batches of pieces, and all the pieces were randomly generated from the 40 possible features. The process plans were generated 
from commercial data of machining times to execute each feature, assuming that the machines of the model are able to execute these features. Table 6 presents the time of execution each feature used in the model.

Each model contains the same number of machines, which can manufacture certain features. Each manufacturing system contains 10 machines, including 2 drilling machines, 2 conventional milling machines, 2 CNC milling machines, 2 conventional lathes and 2 CNC lathes. There are 8 operators and 3 suppliers.

Table 6. Time of execution each feature.

\begin{tabular}{|c|c|c|c|c|c|}
\hline item & Time (min) & Features & item & Time (min) & Features \\
\hline 1 & 0,241274316 & Hole & 21 & 0,251327412 & Knurl \\
\hline 2 & 0,326725636 & Hole & 22 & 0,753982237 & Knurl \\
\hline 3 & 0,41469023 & Hole & 23 & 1,507964474 & Knurl \\
\hline 4 & 0,622035345 & Hole & 24 & 2,261946711 & Knurl \\
\hline 5 & 0,753982237 & Hole & 25 & 3,769911184 & Knurl \\
\hline 6 & 2,226672688 & shoulder & 26 & 0,41887902 & Turn \\
\hline 7 & 2,746334631 & shoulder & 27 & 1,316476922 & Turn \\
\hline 8 & 2,90183953 & shoulder & 28 & 2,333754543 & Turn \\
\hline 9 & 3,444728787 & shoulder & 29 & 4,069110485 & Turn \\
\hline 10 & 4,210224073 & shoulder & 30 & 6,821744048 & Turn \\
\hline 11 & 0,832998052 & slot & 31 & 0,897597901 & Face \\
\hline 12 & 1,09479744 & slot & 32 & 1,361356817 & Face \\
\hline 13 & 1,332796883 & slot & 33 & 1,914875522 & Face \\
\hline 14 & 1,378589181 & slot & 34 & 2,558154018 & Face \\
\hline 15 & 1,670213816 & slot & 35 & 3,291192304 & Face \\
\hline 16 & 1,790575256 & pocket & 36 & 0,515417545 & Groove \\
\hline 17 & 2,064659863 & pocket & 37 & 0,652862223 & Groove \\
\hline 18 & 2,674408561 & pocket & 38 & 0,790306902 & Groove \\
\hline 19 & 2,740812469 & pocket & 39 & 0,927751581 & Groove \\
\hline 20 & 3,367707826 & pocket & 40 & 1,256637061 & Groove \\
\hline
\end{tabular}

In total, all models have 21 resources. With respect to the operators, some of them are dedicated to two different resources, while others are dedicated to only one resource. On the other hand, suppliers are responsible for transporting batches of parts from the entrance to each manufacturing system, transporting them to each machine and, finally, delivering them to the dispatch (exit) of each system. Table 7 presents the 5 different types of machines and the respective features that each machine can manufacture.

Table 7. Types of machines and their operations.

\begin{tabular}{cccc}
\hline Machine & Operation & Process Plan WITHOUT & Process Plan WITH alternatives \\
\hline 1 & Drilling machine & Hole & Hole \\
2 & Milling machine & Shoulder, slot & Hole, shoulder, slot, pocket \\
3 & CNC milling machine & Pocket & Hole, shoulder, slot, pocket \\
4 & Lathe & Knurl, Groove & Turn, face, groove, knurl \\
5 & CNC lathe & Turn, face & Turn, face, groove, knurl \\
\hline
\end{tabular}

In the system with job shop layout the similar resources are arranged in departments, which are the following: milling department, drilling department, CNC milling department, conventional lathes department, and CNC lathes department.

In this system an operator is available for each milling machine, conventional lathes and CNC lathes. For the CNC milling machine and drilling machine, the same operator operates these two machines. In general, the batch of parts enters the system and, according to its process plan, it is led from one department to another. If a department is fully occupied, the batch is held until some department machine is released.

The supplier integrates the transportation system, with the 3 suppliers transporting the batches of parts from one department to the other, from the beginning to the end of batch manufacturing. The supplier can transit between all departments, that is, as soon as a supplier is needed, the one that is available will meet the system's need. 
In the manufacturing system with traditional cell layout, the cells were established by the criterion of the part type of each batch. That is, the parts are based on 40 different features, which are divided into two groups: features for cylindrical parts, and features for prismatic parts.

One of the control factors is the type of demand, which can be totally random, or controlled. Based on the type of demand, three types of cells were established. The first cell only manufactures prismatic parts, consisting of only one drill, one conventional milling machine and one CNC milling machine. In this way, batches of parts formed by strictly prismatic parts will be manufactured in this cell.

A second cell was established to manufacture parts that contain both prismatic features and cylindrical features. This cell is composed of one drill, one conventional milling machine, one conventional milling machine, one conventional lathe and one CNC lathe.

The third cell is designed to manufacture parts that only contain the cylindrical shape, being composed by one conventional lathe and one CNC lathe.

Each cell will have the presence of one supplier, who will be responsible for collecting the raw material at the beginning of the process and dispatching the finished product to the exit of each system. This supplier is dedicated, that is, it does not interact with the cell nor change cells.

Finally, the manufacturing system with virtual cell layout has the same physical distribution as the job shop layout. That is, the machines are distributed in departments, but the logic of the system changes.

When a batch of parts arrives in the system, the system checks all the resources that will be needed to make that batch. All the resources that will be required to make the batch are seized, which form a virtual cell.

As soon as the resources are no longer required to manufacture that batch, they are released and can thus be used by another batch of parts. With regard to suppliers, they have complete freedom to move between departments.

One of the control factors used in this work is related to the type of process plan, that is, if the process plan contains alternatives or not. In the case of a process plan with alternatives, a second resource option is defined for carrying out a given operation.

It was necessary to establish some parameters related to transportation times for each simulation model mentioned. A uniform distribution with a value of 30 to 60 minutes for transportation between departments was established for the job shop and virtual cell layouts, and a uniform distribution of 3 to 6 minutes for the batch to begin processing in the selected resource.

For the traditional cell layout, a uniform distribution of 3 to 6 minutes for cell entry was established, as well as a uniform distribution of 3 to 6 minutes for the start of the operation in each resource.

In addition to the mentioned transportation times, the distances between each resource and the speed with which the suppliers carry out the transportation were also established. In general, the distances were: (a) between the pieces of equipment $=5$ meters; (b) from the system entry to the equipment $=10$ meters; (c) between the equipment and the system exit $=20$ meters. The speed with which the supplier performs the transportation was established at 5 meters per minute for all three models.

Regarding the setup times, the same values were adopted for both models, which were taken from the paper by Hamedi et al. (2012a): (a) drilling machine and lathe $=20$ minutes; (b) milling machine, CNC milling machine, and CNC lathe $=35$ minutes.

For the change of cutting tools in the drilling machine, conventional milling machines and CNC milling machines, a Poisson distribution with average value 60 was set as the interval, and the change time was a normal distribution of 5 to 10 minutes (Mello, 2005). The change of cutting tools in the conventional lathes and CNC lathes was established using a uniform distribution of 5 to 10 minutes for the change interval, and an Erlang distribution with mean equal to 2 for the duration of the tool change (Al-Aomar \& Al -Okaily, 2006).

Another very important value in the model is the failure times of the resources. As already shown in Table 2, maintenance times were established as a control factor in this research, with two levels: high and low. For the maintenance level to be considered high, the manufacturing system must have a maintenance program that seeks to ensure that the machines will not undergo failures and, therefore, the machines will always be available. On the other hand, if the system does not have a specific maintenance plan, it will be subject to resource failures, and this was considered as the low level.

For the drilling machines, conventional milling machines and CNC milling machines, the parameters established by Wang et al. $(1987)$ were used, which establish a Weibull distribution $(17,151 ; 71.4)$ in minutes for the interval between failures, and with constant repair time equal to 96 minutes. For conventional lathes and CNC lathes, 38,400 minutes fault interval values were used, with repair duration of 240 minutes (Devise \& Pierreval, 2000). 
The procedure for the generation of production orders is presented in the flowchart of Figure 3. Some parameters were established as common to the three models, considering that the objective of this work is to compare them.

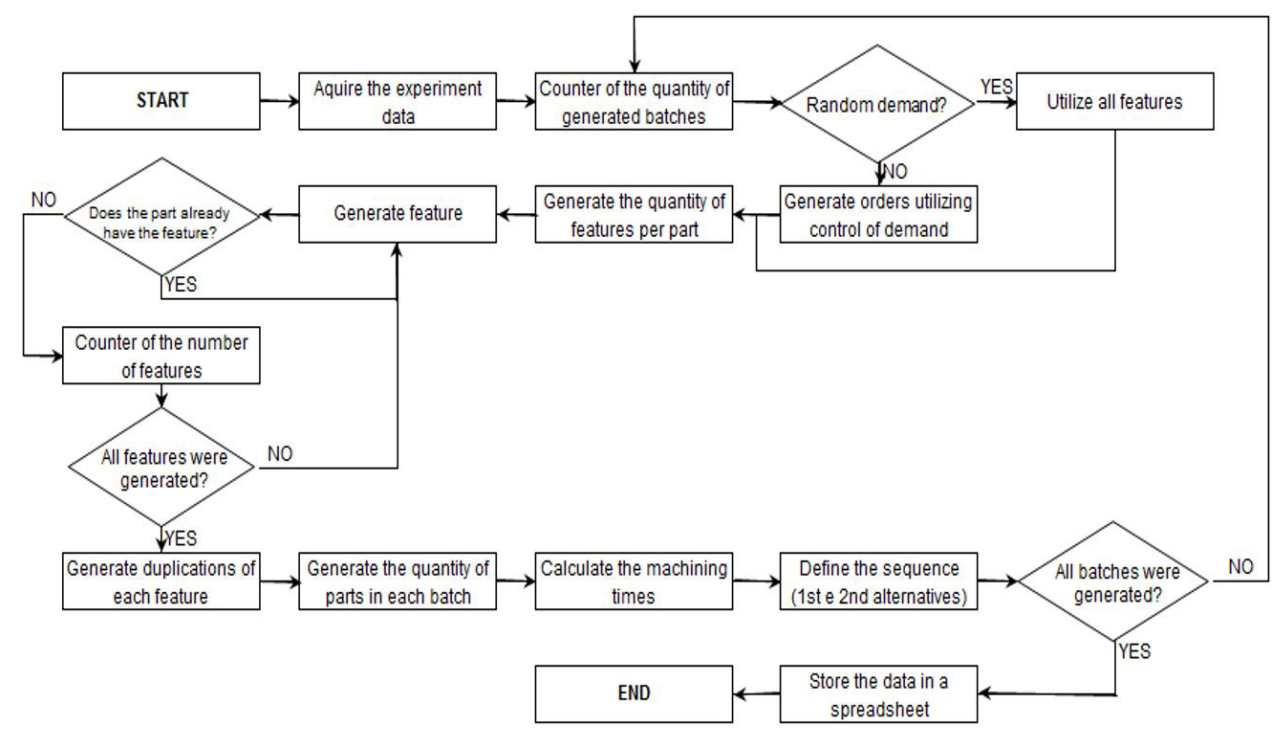

Figure 3. Flowchart for generating the production orders.

Initially, the user specifies the simulation data, such as the type of plan, the number of batches to be simulated, the time of arrival of the next batch, and whether the system will have a maintenance plan. It is also necessary to specify which of the files generated in the previous step will be used in each simulation.

The arrival of a batch is the event that initiates the simulation process, since the arrival time of the first batch is equal to zero. Therefore, considering that batches of parts have already been specified in the previous stage, it is necessary that the model is able to differentiate each batch as to the type of features in each batch, the duplications of features and the quantity of parts in each batch.

Then, according to the features present in each batch of parts, the operations to be performed were specified. Based on the operations, the machines producing the batches can be established. Before checking the machines, it should be verified whether or not the process plan has an alternative.

If the user chooses a process plan without alternatives, the machine specified as the first option to manufacture that feature is selected. On the other hand, if the chosen plan was the one that contains alternatives, it is considered the work in process to select the machine. That is, if the plan has alternatives, before leading to the first or second machine option, the system checks the option that has the lowest queue.

The next stage, which corresponds to the determination of the machining time, is carried out taking into account the type of process plan chosen. In the plan with alternatives, the second machine option has a 40\% penalty attached to the machining time. Once the times are defined, a supplier is required to transport the batch. Whenever it is necessary to enter the system, transport the batch to the next machine or deliver it to dispatch (exit), the supplier was requested. All the transportations that the supplier performs have defined routes and speeds and, thus, the transportation times of the batches of parts can be obtained.

Although all resources were considered available a priori, before carrying out the selected operation, the presence of in-process inventories in the resources was verified. If there is no work in process, the operation is performed immediately, otherwise the waiting time is counted and presented in the simulation report. Before starting machining the batch, the operator sets up the machine.

The batch only leaves the machine when all parts in the batch are machined. In the case of the process plan with alternatives, before leaving the machine, it is verified that the second machine option for the next operation is the same as the current machine. This is done by comparing the work in process in the selected resource to the next operation (first option) with the current resource (second machine option). If the second machine option selected for the next operation is the same as the current machine, an in-process inventory is evaluated to avoid machine change. In this way, the number of setups is significantly reduced. 


\section{ำ}

Finally, it is verified that all operations were performed. If there are no more operations, the batch leaves the system, and its statistical data is collected.

When the simulation comes to an end, with all simulated batches, the report generated by the software is stored with the data that will be used in the calculation of the response variables.

Figure 4 illustrates a flowchart of the activities performed in the simulation of the models of the three layouts.

During the simulation tests the models were simulated at a low speed in order to visualize possible faults, and verify if the model was performing correctly. For this stage of the simulation, animations were set up for the three models, and Figures 5 and 6 illustrate the animations created to aid the verification of the models.

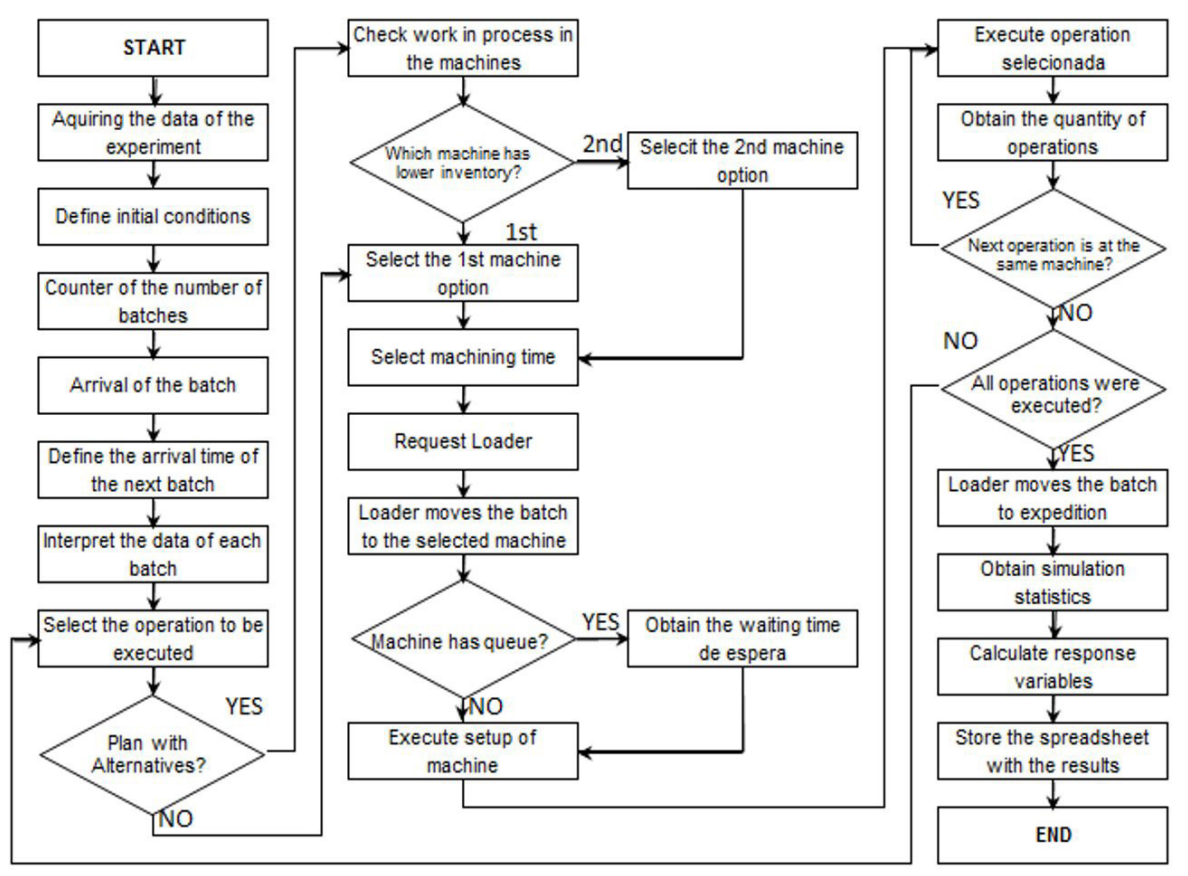

Figure 4. Flowchart for the simulation of the three models.

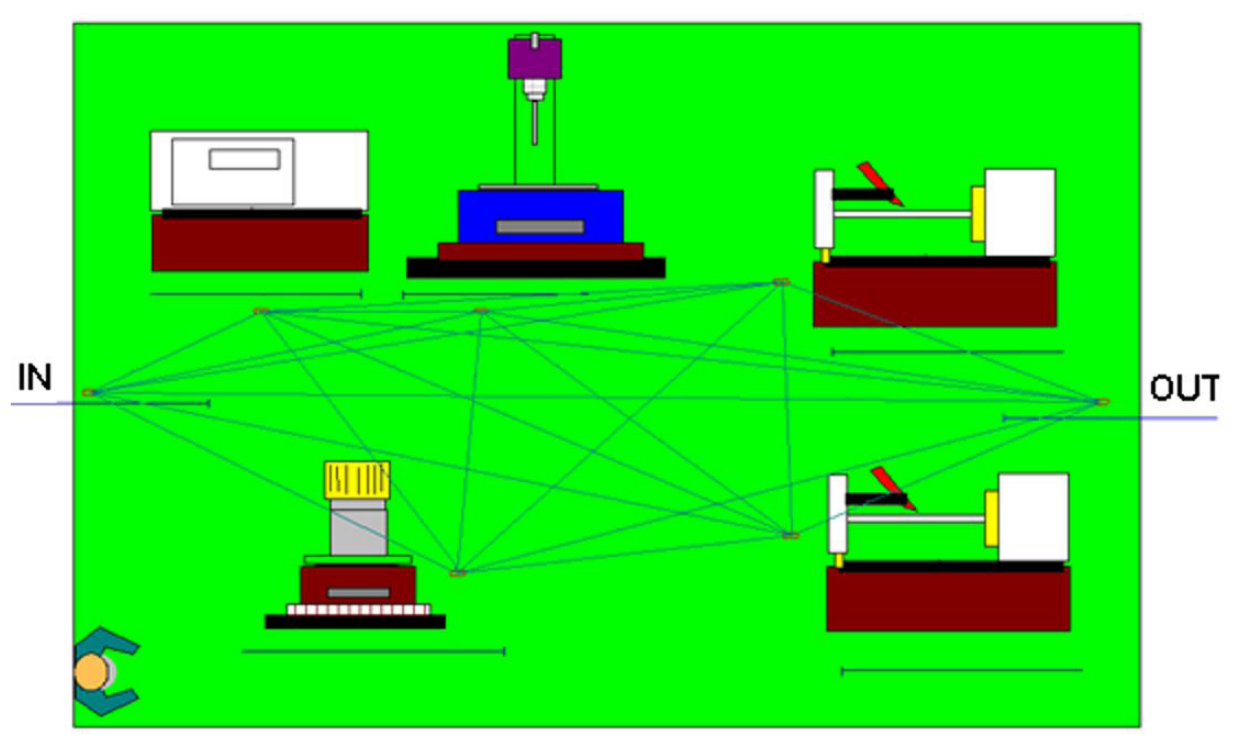

Figure 5. Animation of the job shop and virtual cell layouts. 


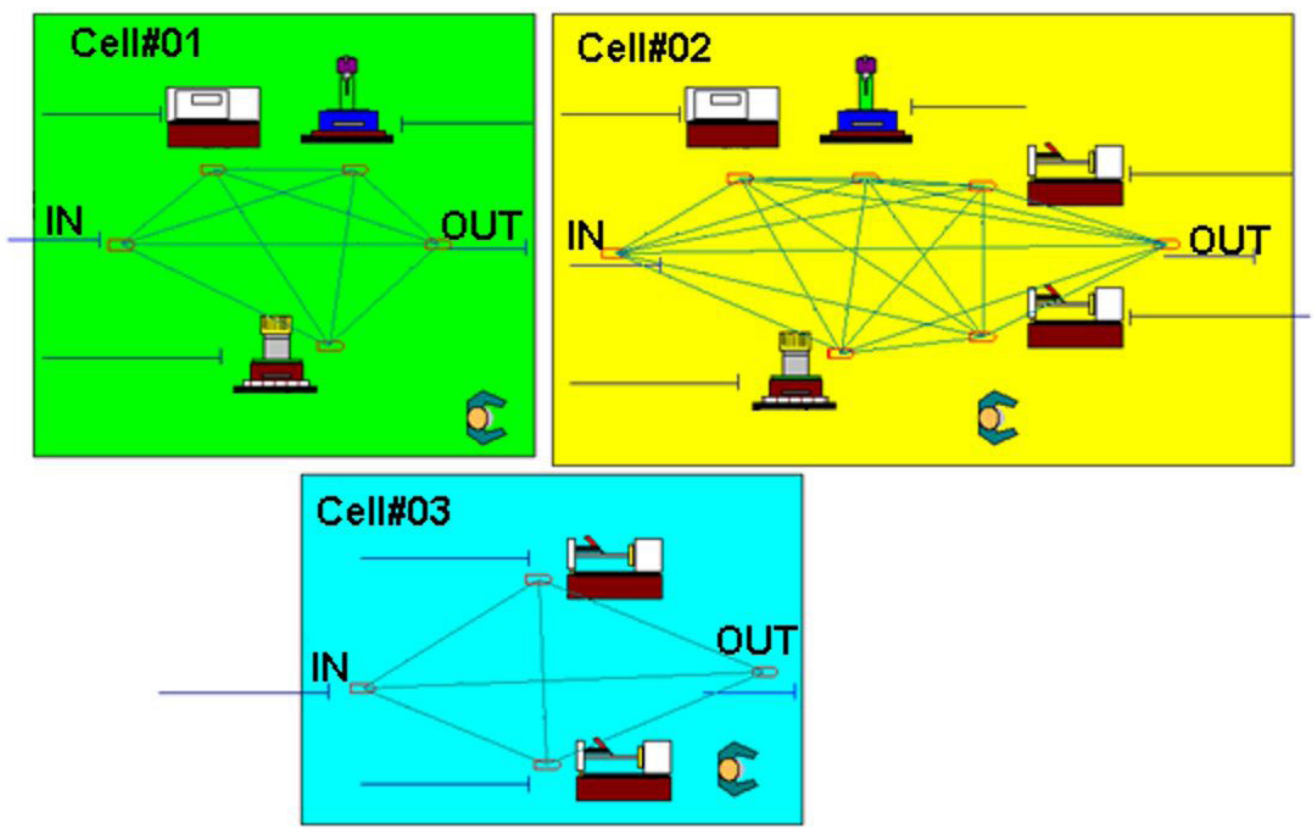

Figure 6. Animation of the traditional cell layout.

\section{Results}

This section is subdivided into two steps. In the first step the results of the analysis of variance (ANOVA) for each type of layout are obtained, comparing each control factor with each of the response variables. Then, in the second stage the layout is analyzed as a control factor of the experiment, and it is verified for which response variables the layout is significant.

\subsection{Results for each layout}

In order to facilitate the understanding of the results, a summary is presented in Table 8, which shows the relationship between each control factor and the response variables for each of the three layouts. It should be mentioned that the analysis of statistical significance was done by using ANOVA (Montgomery, 2012). The "s" was used to represent the statistical significance between the control factor and the response variable, while "ns" illustrates the non-existence of statistical significance. In both cases the level of significance was 0.05.

For the final time response variable (h), the job shop and virtual cell layouts had very similar behavior. They differ from the traditional cell layout in the demand type factor, where the job shop and the virtual cell have a slight increase in the final time when the type of demand is controlled. On the other hand, in the traditional cell layout the final time decreases when the type of demand is controlled, which is in line with the results obtained with traditional cells (Ekren \& Ornek, 2008). However, the average value of the total time for the traditional cell layout was 5000h, while the average value of the total time for the virtual cell layout was $4,000 \mathrm{~h}$, a significant difference.

For the throughput variable (parts/h), the three layouts had similar behaviors. However, the average value of throughput found for the virtual cell layout was better than the traditional cell layout. This is due to the complexity of batches of parts, showing that the virtual cell layout presents greater flexibility. The variable average work in process (parts) presents as key control factor among the three layouts the type of demand, once again evidencing that the formation of the cells dedicated to the type of demand is important. However, the average value of the work in process for the virtual cell layout was smaller than the traditional cell layout. It is noticed that despite the large variation in the demand type, the behavior of the virtual cell layout was more flexible.

For the variable utilization of resources (\%), the virtual cell layout had a performance around 5\% to $10 \%$ higher than the traditional cell layout for some factors. The virtual cell layout had a slight gain in the factor 
Table 8. Comparison between control factors and response variables for each layout.

\begin{tabular}{|c|c|c|c|c|c|c|c|c|c|c|c|c|c|c|c|c|c|c|}
\hline \multirow[b]{3}{*}{ Control Factors } & \multicolumn{18}{|c|}{ Responsable Variables } \\
\hline & \multicolumn{3}{|c|}{ Final Time (h) } & \multicolumn{3}{|c|}{$\begin{array}{l}\text { Throughput } \\
\text { (parts/h) }\end{array}$} & \multicolumn{3}{|c|}{ WIP (parts) } & \multicolumn{3}{|c|}{$\begin{array}{c}\text { Resource } \\
\text { Utilization } \\
(\%)\end{array}$} & \multicolumn{3}{|c|}{$\begin{array}{l}\text { Waiting Total } \\
\text { Time (h) }\end{array}$} & \multicolumn{3}{|c|}{ Lead Time (h) } \\
\hline & JS & TC & $\mathrm{VC}$ & JS & $\mathrm{TC}$ & $\mathrm{vc}$ & JS & $\mathrm{TC}$ & vc & JS & $\mathrm{TC}$ & $\mathrm{vc}$ & JS & $\mathrm{TC}$ & $\mathrm{vc}$ & JS & TC & $\mathrm{VC}$ \\
\hline Features per part & $\mathrm{s}$ & $\mathrm{s}$ & $\mathrm{s}$ & $\mathrm{s}$ & $\mathrm{s}$ & $\mathrm{s}$ & $\mathrm{s}$ & $\mathrm{s}$ & $\mathrm{s}$ & $\mathrm{s}$ & ns & $\mathrm{s}$ & $\mathrm{s}$ & $\mathrm{s}$ & $\mathrm{s}$ & $\mathrm{s}$ & $\mathrm{s}$ & s \\
\hline Duplicated features & s & s & s & s & s & s & ns & ns & ns & s & s & s & s & s & s & s & s & s \\
\hline Batch size & s & s & s & s & s & s & s & s & s & s & s & s & s & s & s & s & s & s \\
\hline Type of demand & ns & ns & ns & ns & s & s & ns & s & ns & s & ns & ns & ns & s & ns & ns & s & ns \\
\hline Type of plan & ns & ns & ns & ns & ns & s & ns & ns & s & s & s & s & ns & ns & ns & ns & ns & ns \\
\hline Simulated batches & s & s & s & s & s & s & s & s & s & s & s & s & s & s & s & s & s & s \\
\hline Arrived time & s & ns & $\mathrm{s}$ & s & s & $\mathrm{s}$ & s & s & $\mathrm{s}$ & s & s & $\mathrm{s}$ & s & s & s & s & s & s \\
\hline Maintenance & ns & ns & ns & ns & ns & ns & ns & ns & s & s & $\mathrm{s}$ & $\mathrm{s}$ & ns & ns & ns & ns & ns & ns \\
\hline \multicolumn{8}{|c|}{ JS - job shop layout; TC - Traditional Cell layout } & \multicolumn{11}{|c|}{ s - with statistical significance } \\
\hline \multicolumn{7}{|c|}{ VC - Virtual Cell Layout } & & \multicolumn{11}{|c|}{ ns - without statistical significance } \\
\hline
\end{tabular}

arrival time between batches. That is, the job shop layout had a smaller variation when the level of this factor increased.

As for the factor type of demand, the virtual cell layout proved to be better than the job shop and the traditional cell layout. That is, it was more efficient when the level of this factor was changed, showing that the virtual cell layout really can present the virtues of the other two layouts.

It should be noticed the increase in resource utilization when the systems were managed with a maintenance plan, which left the machines always available. This shows that maintenance is a very important factor for production systems.

The response variable total waiting time (hours) also had different results for the three layouts. The virtual cell layout had an average value of waiting time lower than the other two layouts.

Finally, for the variable lead time, which corresponds to the total time for moving from the entry of the raw material to the finished product, it presented very similar results for the three models. The virtual cell layout underwent fewer variations when the levels of each factor were changed. This shows that this type of layout has greater robustness when variations in some factors take place.

\subsection{Comparison between layouts}

In this second stage of results analysis the type of layout was included as a control factor with three levels: job shop, traditional cell, and virtual cell. It was verified how the response variables behaved in relation to the type of layout. This analysis of statistical significance was based on the value of P using ANOVA. lt is noticed in Table 9 that the type of layout has statistical significance ("s") for all response variables to the significance level of 0.05 .

Table 9. Comparison between control factors and response variables.

\begin{tabular}{ccccccc}
\hline \multirow{2}{*}{ Control Factors } & \multicolumn{5}{c}{ Responsable Variables } \\
\cline { 2 - 7 } & Final Time (h) & $\begin{array}{c}\text { Throughput } \\
\text { (parts/h) }\end{array}$ & WIP (parts) & $\begin{array}{c}\text { Resource } \\
\text { Utilization (\%) }\end{array}$ & $\begin{array}{c}\text { Waiting Total } \\
\text { Time (h) }\end{array}$ & Lead Time (h) \\
\hline Layout type & $\mathrm{s}$ & $\mathrm{s}$ & $\mathrm{s}$ & $\mathrm{s}$ & $\mathrm{s}$ & $\mathrm{s}$ \\
Features per part & $\mathrm{s}$ & $\mathrm{s}$ & $\mathrm{s}$ & $\mathrm{s}$ & $\mathrm{s}$ & $\mathrm{s}$ \\
Duplicated features & $\mathrm{s}$ & $\mathrm{s}$ & $\mathrm{ns}$ & $\mathrm{s}$ & $\mathrm{s}$ & $\mathrm{s}$ \\
Batch size & $\mathrm{s}$ & $\mathrm{s}$ & $\mathrm{s}$ & $\mathrm{s}$ & $\mathrm{s}$ & $\mathrm{s}$ \\
Type of demand & $\mathrm{ns}$ & $\mathrm{ns}$ & $\mathrm{ns}$ & $\mathrm{ns}$ & $\mathrm{s}$ & $\mathrm{ns}$ \\
Type of plan & $\mathrm{ns}$ & $\mathrm{ns}$ & $\mathrm{ns}$ & $\mathrm{s}$ & $\mathrm{s}$ & $\mathrm{s}$ \\
Simulated batches & $\mathrm{s}$ & $\mathrm{s}$ & $\mathrm{s}$ & $\mathrm{s}$ & $\mathrm{s}$ & $\mathrm{s}$ \\
Arrived time & $\mathrm{s}$ & $\mathrm{s}$ & $\mathrm{s}$ & $\mathrm{s}$ & $\mathrm{s}$ & $\mathrm{ns}$ \\
Maintenance & $\mathrm{ns}$ & $\mathrm{ns}$ & $\mathrm{ns}$ & $\mathrm{ns}$ & & $\mathrm{s}$ \\
\hline
\end{tabular}


Regarding the final time, Figure 7 shows that the traditional cell layout had a significant increase in relation to the job shop and virtual cell layouts. On average, the virtual cell layout had a performance $23 \%$ higher than the traditional cellular layout, and practically the same as in the job shop $(-1.5 \%)$. However, observing the confidence interval with a confidence level of 95\% (Table 6), statistically it cannot be stated that the mean values are different.

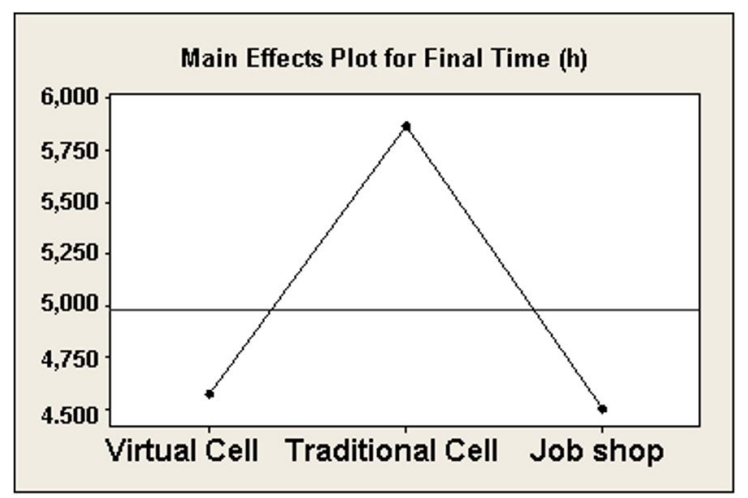

Figure 7. Main effects plot of the final time in the layouts.

The cells highlighted in Table 10 shows the three factors in which the confidence intervals do not intersect between the virtual cell and the traditional cellular layouts.

Table 10. Confidence intervals for the three layouts.

\begin{tabular}{cccc}
\hline & Virtual Cell Layout & Traditional Cell Layout & Job shop layout \\
\hline Final Time (h) & $3,502.4 \leq \mu \leq 5,639.1$ & $4,500.1 \leq \mu \leq 7,239.0$ & $3,442.8 \leq \mu \leq 5,553.5$ \\
Throughput (parts/h) & $11.22 \leq \mu \leq 14.22$ & $9.74 \leq \mu \leq 12.57$ & $11.57 \leq \mu \leq 14.68$ \\
WIP (parts) & $3,103.6 \leq \mu \leq 4,741.8$ & $4,290.7 \leq \mu \leq 6,509.6$ & $3,396.0 \leq \mu \leq 5,281.6$ \\
Resource Utilization (\%) & $0.315 \leq \mu \leq 0.346$ & $0.250 \leq \mu \leq 0.273$ & $0.320 \leq \mu \leq 0.353$ \\
Waiting Total Time (h) & $345.3 \leq \mu \leq 734.3$ & $979.8 \leq \mu \leq 2,019.1$ & $379.9 \leq \mu \leq 826.2$ \\
Lead Time (h) & $509.9 \leq \mu \leq 940.5$ & $1,136.6 \leq \mu \leq 2,218.8$ & $543.4 \leq \mu \leq 1,030.2$ \\
\hline
\end{tabular}

Figure 8 associates throughput with the layouts, showing a better performance by the job shop and virtual cell layouts when compared with the traditional cell layout. The performance of the virtual cell layout was better than the traditional cell layout by about 12\%. For the job shop layout the difference was only 3\% on average. However, observing the confidence interval (confidence level of 95\%) (Table 6), statistically it cannot be stated that these values are different.

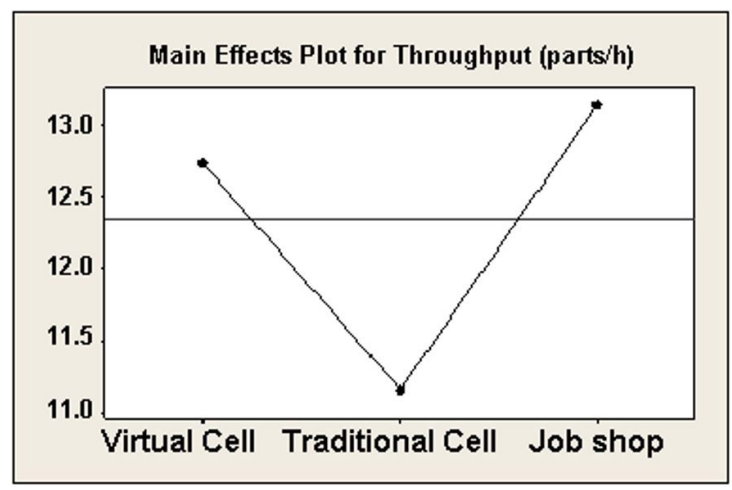

Figure 8. Main effects plot of the layouts for throughput. 
Figure 9 shows how the layouts behaved in relation to the average work in process. In this response variable, the job shop and virtual cell layouts again present better performance, and the virtual cell layout was still better than the job shop. The virtual cell layout was better in approximately $27 \%$ in relation to the traditional cell layout, while for the job shop layout the superiority was 10\%. This shows that the virtual cell layout can be located between job shop and traditional cell layouts, having advantages of both. However, observing the confidence interval (confidence level of 95\%) (Table 6), statistically it cannot be stated that these values are different.

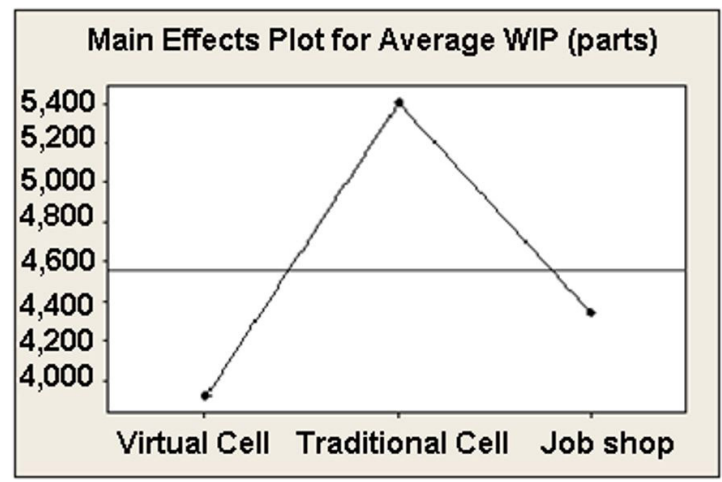

Figure 9. Main effects plot of the average WIP in the layouts.

Figure 10 illustrates the behavior of the type of layout with respect to the response variable referred to as average resource utilization. Once again, the job shop and virtual cell layouts outperformed the traditional cell layout. The virtual cell layout had a resource utilization 20\% higher than the traditional cell layout. Observing the confidence interval (confidence level equal to 95\%) (Table 6), it can be stated that the values between the virtual cell and traditional cell systems are different.

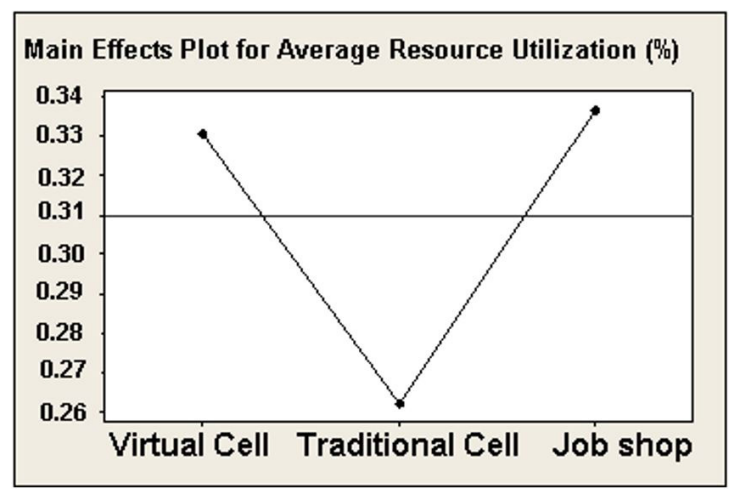

Figure 10. Main effects plot of the resource use in the layouts.

Figures 11 and 12 show the behavior of the layouts with respect to the waiting total time and lead time variables, respectively. It is noticed a very similar behavior for both cases, where again the virtual cell and job shop layouts performed better.

With regard to the waiting time, the performance of the virtual cell layout was again better than the others, about $10 \%$ in the average with respect to the job shop layout, and far better than the traditional cell layout (about 50\%). Observing the confidence interval (confidence level of 95\%) (Table 6), it can be stated that the values between the virtual cell and traditional cell layouts are different.

Regarding lead time, on average the virtual cell layout had a good result, approximately $7 \%$ shorter than the job shop, and 50\% shorter than the traditional cell layout. Observing the confidence interval (Table 6) (confidence level equal to 95\%), it can be affirmed that the values between the virtual cell and traditional cell 


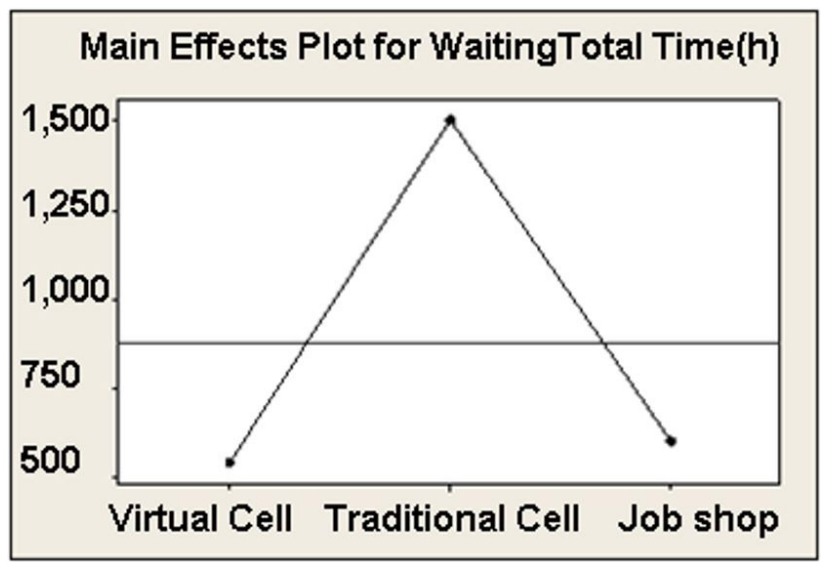

Figure 11. Main effects plot of the waiting time in the layouts.

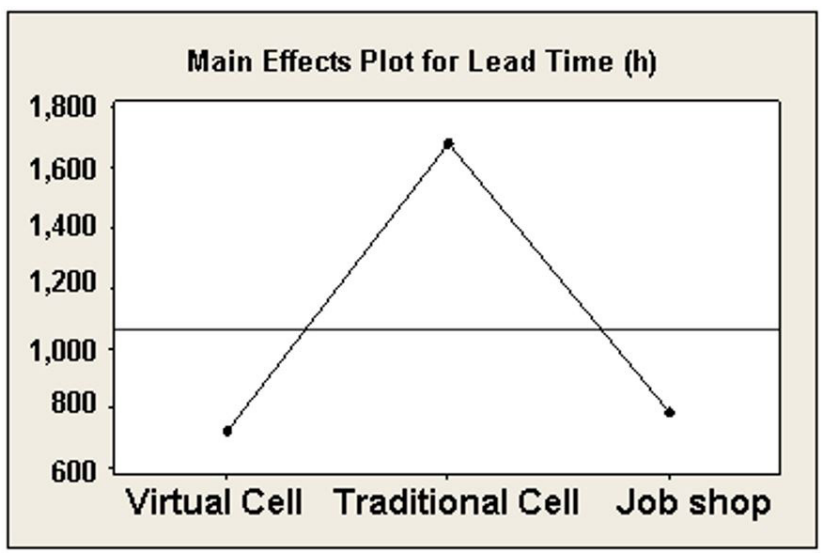

Figure 12. Main effects plot of the lead time in the layouts.

layouts are different. In summary, Table 11 presents the performance of each layout for the response variables, always having the virtual cellular layout as the reference of the comparison. The minus sign indicates a worse result when compared to the virtual cell, and the plus signal indicates a better result compared to the virtual cell.

Table 11. Summary of comparison percentages.

\begin{tabular}{cccc}
\hline & Virtual Cell Layout & $\begin{array}{c}\text { Traditional Cell } \\
\text { Layout }\end{array}$ & Job shop layout \\
\hline Final Time (h) & 0 & $-23 \%$ & $+1,5 \%$ \\
Throughput (parts/h) & 0 & $-12 \%$ & $+3 \%$ \\
WIP (parts) & 0 & $-27 \%$ & $+10 \%$ \\
Resource Utilization (\%) & 0 & $-20 \%$ & Equal \\
Waiting Total Time (h) & 0 & $-50 \%$ & $-10 \%$ \\
Lead Time (h) & 0 & $-50 \%$ & $-7 \%$ \\
\hline
\end{tabular}

\section{Conclusion}

The aim of this research was to compare the virtual cell layout with other types of layout. It has a performance similar to the job shop layout, but it is better than the traditional cell layout. In addition, a greater number of control factors and response variables were considered compared with previous studies such as Mello (2005) and Reaes (2008). This greater amount of response variables provided a broader analysis of the three layouts. 
In general, such different results found in the case of the traditional cell layout can be understood by the wide variety of parts. Similar results were found by Ramachandran \& Prasad (2014). All parts in each batch were generated from 40 pre-established features, and Excel's random function resulted in high batch variability, leading to a poor performance of the traditional cell layout.

A significant factor for the poorer performance of the traditional cell layout was the parts supplier. By leaving the supplier working exclusively in the cell, there was an imbalance of this operation, that is, while in a cell the supplier worked uninterruptedly, while the supplier became idle in the cell for cylindrical parts. This behavior influenced the processing times, and reduced throughput and resource utilization.

Another issue to be considered is the continuous flow, which, in the case considered in this paper, did not take place as in the traditional cell layout, since the production was based on batches of parts and not one piece flow. The setup times were the same for all three layouts, and the only difference occurred in entry of the batch in the cells, when the time was ten times shorter for the traditional cell layout when compared to the virtual cell and job shop layouts.

Moreover, as Ramachandran \& Prasad (2014) suggest, the transition from the job shop layout to the virtual cell layout is easier when compared with the costs involved in the case of the transition to the traditional cell layout.

The objective of showing a knowledge gap with respect to virtual cells signals the importance of this topic, and the possibilities that have not yet been investigated about it in manufacturing companies. As a suggestion of future work, the amount of levels of some factors can be increased, which would improve the focus on the influence of certain factors on the response variables. Another suggestion would be the exclusion of one or more factors, seeking to focus on factors that can be directly controlled in the manufacturing system without depending on the interference of the customers. For example, factors such as features per part are customer requirements, and can hardly be influenced by the system.

With regard the papers limitations: the use of a process plan with alternatives, it is suggested to include an additional level for this factor, or two different penalties, in order to investigate the gains that are pointed out in the literature. It is suggested to address the issue of operator flexibility, which was implemented in a simplified way in this research. A study should be carried out relating the results found in this paper with the equipment costs, which may originate from obsolescence, maintenance, upgrade and replacement.

\section{Reference}

Agarwal, A., \& Sarkis, J. (2001). Evaluating functional and cellular manufacturing systems: a model and case analysis. International Journal of Manufacturing Technology and Management, 3(6), 528-549. http://dx.doi.org/10.1504/1JMTM.2001.001428.

Al-Aomar, R., \& Al-Okaily, A. (2006). A GA-based parameter design for single machine turning process with high-volume production. Computers \& Industrial Engineering, 50(3), 317-337. http://dx.doi.org/10.1016/j.cie.2006.02.003.

Alhourani, F. (2015). Cellular manufacturing system design considering machines reliability and parts alternative process routings. International Journal of Production Research, 54(3), 846-863. http://dx.doi.org/10.1080/00207543.2015.1083626.

Andersen, A.-L., Brunoe, T. D., Nielsen, K., \& Rösiö, C. (2017). Towards a generic design method for reconfigurable manufacturing systems. Journal of Manufacturing Systems, 42, 179-195. http://dx.doi.org/10.1016/j.jmsy.2016.11.006.

Andrade, J. H. D., \& Fernandes, F. C. F. (2018). Barriers and challenges to improve interfunctional integration between Product Development and Production Planning and Control in Engineering-to-Order Environment. Gestão \& Produção, 25(3), 610-625. http://dx.doi.org/10.1590/0104-530x1087-13.

Arkat, J., \& Ghahve, H. (2014). Scheduling of virtual manufacturing cells with outsourcing allowed. International Journal of Computer Integrated Manufacturing, 27(12), 1079-1089. http://dx.doi.org/10.1080/0951192X.2013.874581.

Assad, A. A., Kramer, S. B., \& Kaku, B. K. (2003). Comparing functional and cellular layouts: A simulation study based on standardization. International Journal of Production Research, 41(8), 1639-1663. http://dx.doi.org/10.1080/0020754021000049790.

Bazargan-Cart, M., \& Nahavandi, S. (2001). The Impact of Cell Formation on Layout Designs in Cellular Manufacturing. Intelligent Automation \& Soft Computing, 71), 13-22. http://dx.doi.org/10.1080/10798587.2001.10642800.

Cheng Ying, N., Ab-Samat, H., \& Kamaruddin, S. (2016). Pratical Production layout design for multi-product and small-lot-size production: A case study. Journal Teknologi, 78(7), 161-175.

Chin, S. Y. (2013). Virtual Cells: Evalution of different lot sizing splitting strategies. International Journal of Manufacturing Research, 8(1), 18-41. http://dx.doi.org/10.1504/1JMR.2013.051838.

Colosimo, B., Semeraro, Q., \& Tolio, T. A. (2000). Rule based system for non linear process plan generation. Studies in Informatics and Control, 9(2) 133-143.

Costa, R. F. S. (2010). Abordagem sistemática para avaliação econômica de cenários para modelos de simulação discreta em manufatura. (Dissertação de mestrado). Instituto de Engenharia de Produção e Gestão, Universidade Federal de ltajubá, Itajubá.

Dakov, 1., Lefterova, T., \& Petkova, A. (2010). Layout and Production Planning of Virtual Cellular Manufacturing Systems for Mechanical Machining. Journal of Economic Asymmetries, 71), 43-67. http://dx.doi.org/10.1016/j.jeca.2010.01.004.

Deep, K., \& Singh, P. K. (2016). Dynamic cellular manufacturing system design considering alternative routing and part operation tradeoff using simulated annealing based genetic algorithm. Shadana, 41(9), 1063-1079. 
Defersha, F. M., \& Hodiya, A. (2017). A mathematical model and a parallel multiple search path simulated annealing for an integrated distributed layout design and machine cell formation. Journal of Manufacturing Systems, 43, 195-212. http://dx.doi.org/10.1016/j. jmsy.2017.04.001.

Deja, M., \& Siemiatkowski, M. (2010). Generation of Optimal Process Plan Alternatives for Manufacturing Mechanical Components. Solid State Phenomena, 165, 250-255. http://dx.doi.org/10.4028/www.scientific.net/SSP.165.250.

Deja, M., \& Siemiatkowski, M. S. (2012). Feature-based generation of machining process plans for optimised parts manufacture. Journal of Intelligent Manufacturing, 24(4), 831-846. http://dx.doi.org/10.1007/s10845-012-0633-x.

Devise, 0., \& Pierreval, H. (2000). Indicators for measuring performances of morphology and material handling systems in flexible manufacturing systems. International Journal of Production Economics, 64(1-3), 209-218. http://dx.doi.org/10.1016/S09255273(99)00059-6.

Dias, L. M. S., Pereira, G. A. B., Vik, P., \& Oliveira, J. A. (2014). Layout and process optimisation: using computer-aided design (CAD) and simulation through an integrated systems design tool. International Journal of Simulation and Process Modelling, 9(1/2), 46. http://dx.doi.org/10.1504/1JSPM.2014.061437.

Drira, A., Pierreval, H., \& Hajri-Gabouj, S. (2007). Facility layout problems: A survey. Annual Reviews in Control, 31(2), 255-267. http:// dx.doi.org/10.1016/j.arcontrol.2007.04.001.

Drolet, J., Marcoux, Y., \& Abdulnour, G. (2008). Simulation-based performance comparison between dynamic cells, classical cells and job shops: a case study. International Journal of Production Research, 46(2), 509-536. http://dx.doi.org/10.1080/00207540601138312.

Ekren, B. Y., \& Ornek, A. M. (2008). A simulation based experimental design to analyze factors affecting production flow time. Simulation Modelling Practice and Theory, 16(3), 278-293. http://dx.doi.org/10.1016/j.simpat.2007.11.016.

Ertay, T. (1998). Simulation approach in comparison of a pull system in a cell production system with a push system in a conventional production system according to flexible cost: A case study. International Journal of Production Economics, 56-57, 145-155. http:// dx.doi.org/10.1016/S0925-5273(98)00035-8.

Ferreira, J. C. E., \& Reaes, P. A. (2013, Ago 17-20). Performance comparison of the virtual cell layout with cellular and job shop configurations using simulation and design of experiments. In IEEE International Conference on Automation Science and Engineering (pp. 795-800). Wisconsin: IEEE Robotics and Automation Society. http://dx.doi.org/10.1109/CoASE.2013.6654054.

Ferreira, J. C. E., \& Wysk, R. A. (2001a). An investigation of the influence of alternative process plans on equipment control. Journal of Manufacturing Systems, 19(6), 393-406. http://dx.doi.org/10.1016/S0278-6125(01)80011-X.

Ferreira, J. C. E., \& Wysk, R. A. (2001b). On the efficiency of alternatives in process plans. Journal of the Brazilian Society of Mechanical Sciences, 23(3), 285-302. http://dx.doi.org/10.1590/S0100-73862001000300003.

Freitas Filho, F. P. (2008). Introduction to Modeling and Simulation of Systems: with applications in Arena ${ }^{\circledR}$. (2nd ed.). Florianópolis: Visual Books.

Fuchigami, H. Y., Moccellin, J. V., \& Ruiz, R. (2015). Novas regras de prioridade para programação em flexible flow line com tempos de setup explícitos. Production, 25(4), 779-790.http://dx.doi.org/10.1590/0103-6513.089212

Fung, R. Y. K., Liang, F., Jiang, Z., \& Wong, T. N. (2006). A multi-stage methodology for virtual cell formation oriented agile manufacturing. International Journal of Advanced Manufacturing Technology, 36(7-8), 798-810. http://dx.doi.org/10.1007/s00170-006-0871-1.

Garza-Reyes, J. A., Al-Balushi, M., Antony, J., \& Kumar, V. (2016). A Lean Six Sigma framework for the reduction of ship loading commercial time in the iron ore pelletising industry. Production Planning and Control, 27(13), 1092-1111. http://dx.doi.org/10.10 80/09537287.2016.1185188.

Gomes, J. H. F. (2010). Análise e otimização da soldagem de revestimento de chapas de aço carbono utilizando arame tubular inoxidável austenítico. 136 p. (Dissertação de mestrado). Universidade Federal de ltajubá, Itajubá.

Gupta, A., Jain, P. K., \& Kumar, D. (2015). Configuration selection of reconfigurable manufacturing system based on performance. International Journal of Industrial and Systems Engineering, 20(2), 209. http://dx.doi.org/10.1504/1JISE.2015.069543.

Haddou Benderbal, H., Dahane, M., \& Benyoucef, L. (2017). Flexibility-based multi-objective approach for machines selection in reconfigurable manufacturing system (RMS) design under unavailability constraints. International Journal of Production Research, 55(20), 6033-6051. http://dx.doi.org/10.1080/00207543.2017.1321802.

Hamedi, M., Esmaeilian, G. R., Napsiah, 1., \& Ariffin, M. K. A. (2012a). A survey on formation of virtual cellular manufacturing systems (VCMSs) and related issues. Scientific Research and Essays, 740), 3316-3328. http://dx.doi.org/10.5897/SRE11.217.

Hamedi, M., Esmaeilian, G. R., Napsiah, 1., \& Ariffin, M. K. A. (2012b). Capability-based virtual cellular manufacturing systems formation in dual-resource constrained settings using Tabu Search. Computers \& Industrial Engineering, 62(4), 953-971. http://dx.doi. org/10.1016/j.cie.2011.12.020.

Hamedi, H., Ismail, N., Esmaeilian, G. R., \& Ariffin, M. K. A. (2012c). Virtual cellular manufacturing system based on resource element approach and analyzing its performance over different basic layouts. International Journal of Industrial Engineering Computations, 3(2), 265-276. http://dx.doi.org/10.5267/j.ijiec.2011.07.002.

Hamedi, M., \& Esmaeilian, G. (2015, March 3-5). Functional and distributed layouts and their effectiveness on capability-based Virtual Cellular Manufacturing systems performance. In International Conference on Industrial Engineering and Operations Management. Dubai: IEEE. http://dx.doi.org/10.1109/1EOM.2015.7093847.

Javadi, B., Jolai, F., Slomp, J., Rabbani, M., \& Tavakkoli-Moghaddam, R. (2013). An integrated approach for the cell formation and layout design in cellular manufacturing systems. International Journal of Production Research, 51(20), 6017-6044. http://dx.doi. org/10.1080/00207543.2013.791755.

Jayachitra, R., \& Prasad, P. S. S. (2011). Performance analysis of Virtual Cellular Manufacturing: a simulation study. International Journal of Services and Operations Management, 8(1), 92. http://dx.doi.org/10.1504/1JSOM.2011.037442.

Jayachitra, R., Revathy, R., \& Prasad, P. S. S. (2010). A Fuzzy programming approach for formation of virtual cells under dynamic and uncertain conditions. International Journal of Engineering Science and Technology, 2(6), 1708-1724.

Jerbi, A., Chtourou, H., \& Maalej, A. Y. (2010). Comparing functional and cellular layouts using simulation and Taguchi method. Journal of Manufacturing Technology Management, 21(5), 529-538. http://dx.doi.org/10.1108/17410381011046940. 
Kamaruddin, S., Khoo, S. Y., Khan, Z. A., \& Siddiquee, A. N. (2011). The effect of layout design on productivity: an empirical study. International Journal of Productivity and Quality Management, 74), 484. http://dx.doi.org/10.1504/IJPQM.2011.040545.

Karl, A. A., Micheluzzi, J., Leite, L. R., \& Pereira, C. R. (2018). Supply chain resilience and key performance indicators: a systematic literature review. Production, 28(0), e20180020. http://dx.doi.org/10.1590/0103-6513.20180020.

Khaksar-Haghani, F., Kia, R., Mahdavi, l., \& Kazemi, M. (2012). A genetic algorithm for solving a multi-floor layout design model of a cellular manufacturing system with alternative process routings and flexible configuration. International Journal of Advanced Manufacturing Technology, 66(5-8), 845-865. http://dx.doi.org/10.1007/s00170-012-4370-2.

Khilwani, N., Ulutas, B. H., Islier, A. A., \& Tiwari, M. K. (2011). A methodology to design virtual cellular manufacturing systems. Journal of Intelligent Manufacturing, 22(4), 533-544. http://dx.doi.org/10.1007/s10845-009-0314-6.

Kleijnen, J. P. C., Sanchez, S. M., Lucas, T. W., \& Cioppa, T. M. (2005). State-of-the-Art Review: A User's guide to the brave new world of designing simulation experiments. INFORMS Journal on Computing, 17(3), 263-289. http://dx.doi.org/10.1287/ijoc.1050.0136.

Kongchuenjai, J., \& Prombanpong, S. (2017). An integer programming approach for process planning for mixed-model parts manufacturing on a CNC machining center. Advances in Production Engineering \& Management, 12(3), 274-284. http://dx.doi. org/10.14743/apem2017.3.258.

Lv, J., Xiong, L. L., \& Han, W. M. (2014). Discussion on the application of activity-based costing in virtual manufacturing cell mode. Applied Mechanics and Materials, 551, 290-295. http://dx.doi.org/10.4028/www.scientific.net/AMM.551.290.

Mahdavi, 1., Aalaei, A., Paydar, M. M., \& Solimanpur, M. (2011). Multi-objective cell formation and production planning in dynamic virtual cellular manufacturing systems. International Journal of Production Research, 49(21), 6517-6537. http://dx.doi.org/10.10 80/00207543.2010.524902.

Mar-Ortiz, J., Adenso-Díaz, B., \& González-Velarde, J. L. (2015). A comparison of manufacturing and disassembly systems from a cellular configuration point of view. International Journal of Advanced Manufacturing Technology, 79(9-12), 2003-2016. http:// dx.doi.org/10.1007/s00170-015-6969-6.

Mclean, C. R., Bloom, H., \& Hopp, T. H. (1982). The virtual manufacturing cell. In Proceedings of fourth IFAC/IFIP Conference on Information Control Problems in Manufacturing Technology (pp. 105-111). Gaithersburg: IFAC/IFIP.

Mclean, R. S., \& Antony, J. (2017). A conceptual continuous improvement implementation framework for UK manufacturing companies. International Journal of Quality \& Reliability Management, 34(7), 1015-1033. http://dx.doi.org/10.1108/lJQRM-02-2016-0022.

Medina-Herrera, N., Jiménez-Gutiérrez, A., \& Grossmann, l. E. (2014). A mathematical programming model for optimal layout considering quantitative risk analysis. Computers \& Chemical Engineering, 68, 165-181. http://dx.doi.org/10.1016/j.compchemeng.2014.05.019.

Mello, M. H. (2005). Avaliação do Desempenho de Alternativas em Planos de Processo utilizando Simulação e Projeto de Experimentos. (Dissertação de mestrado). Departamento de Engenharia Mecânica, Universidade Federal de Santa Catarina, Florianópolis.

Mesquita, M. A.; Mariz, F. B. A. R.; \& Tomotani, J. V. (2017). The Skateboard Factory: a teaching case on discrete-event simulation. Production, 27(spe), 1-11.http://dx.doi.org/10.1590/0103-6513.226216.

Montevechi, J. A. B., de Pinho, A. F., Leal, F., \& Marins, F. A. S. (2007, January 4). Application of design of experiments on the simulation of a process in automotive industry. In Winter Simulation Conference. Washington: IEEE. http://dx.doi.org/10.1109/WSC.2007.4419779

Montgomery, D. C. (2012). Design and Analysis of Experiments (8th ed.). New York: Wiley.

Morales, S.G.; \& Ronconi, D.P. (2015). Formulações matemáticas e estratégias de resolução para o problema job shop clássico. Production, 26(3), 614-625.http://dx.doi.org/10.1590/0103-6513.058512

Morris, J. S., \& Tersine, R. J. (1994). A simulation comparison of process and cellular layouts in a dual resource constrained environment. Computers \& Industrial Engineering, 26(4), 733-741. http://dx.doi.org/10.1016/0360-8352(94)90008-6.

Murthy, P. B. G. S. N., Ranganayakulu, J., Vidhu, K. P., \& Rao, K. V. (2016). Heuristic Search Algorithm for the Single-row Machine Layout in an Automated Manufacturing System. Procedia Technology, 25, 1088-1095. http://dx.doi.org/10.1016/j.protcy.2016.08.213.

Paydar, M. M., \& Saidi-Mehrabad, M. (2014). Revised multi-choice goal programming for integrated supply chain design and dynamic virtual cell formation with fuzzy parameters. International Journal of Computer Integrated Manufacturing, 28(3), 251-265. http:// dx.doi.org/10.1080/0951192X.2013.874596.

Paydar, M. M., \& Saidi-Mehrabad, M. (2017). A hybrid genetic algorithm for dynamic virtual cellular manufacturing with supplier selection. International Journal of Advanced Manufacturing Technology, 92(5-8), 3001-3017. http://dx.doi.org/10.1007/s00170-017-0370-6.

Phanden, R. K., Jain, A., \& Verma, R. (2013). An approach for integration of process planning and scheduling. International Journal of Computer Integrated Manufacturing, 26(4), 284-302. http://dx.doi.org/10.1080/0951192X.2012.684721.

Rabbani, M., Farrokhi-Asl, H., \& Ravanbakhsh, M. (2018). Dynamic cellular manufacturing system considering machine failure and workload balance. Journal of Industrial Engineering International, 14(1), 1-16. http://dx.doi.org/10.1007/s40092-018-0261-y

Rajapakshe, T., Dawande, M., \& Sriskandarajah, C. (2011). Quantifying the Impact of Layout on Productivity: An Analysis from RoboticCell Manufacturing. Operations Research, 59(2), 440-454. http://dx.doi.org/10.1287/opre.1100.0874.

Ramachandran, J., \& Prasad, P. S. (2014). Facility layout selection guideline under dynamic demand and part variety. Journal of Engineering Technology, 4(1), 55. http://dx.doi.org/10.4103/0976-8580.123806.

Reaes, P. A. (2008). Comparação de desempenho entre as configurações celular, job shop e celular virtual através de simulação e projeto de experimentos (Tese de doutorado). Departamento de Engenharia Mecânica, Universidade Federal de Santa Catarina, Florianópolis.

Rezazadeh, H., Ghazanfari, M., Sadjadi, S. J., Aryanezhad, M., \& Makui, A. (2009). Linear programming embedded particle swarm optimization for solving an extended model of dynamic virtual cellular manufacturing systems. Journal of applied research and technology, 7(1), 83-108.

Rheault, M., Drolet, J. R., \& Abdulnour, G. (1995). Physically reconfigurable virtual cells: A dynamic model for a highly dynamic environment. Computers \& Industrial Engineering, 29(1-4), 221-225. http://dx.doi.org/10.1016/0360-8352(95)00075-C.

Sakhaii, M., Tavakkoli-Moghaddam, R., Bagheri, M., \& Vatani, B. (2016). A robust optimization approach for an integrated dynamic cellular manufacturing system and production planning with unreliable machines. Applied Mathematical Modelling, 40(1), $169-191$. http://dx.doi.org/10.1016/j.apm.2015.05.005. 
Sanchez, S. M. (2008, December 7-10). Better than a petaflop: The power of efficient experimental design. In 2008 Winter Simulation Conference. Miami: IEEE. http://dx.doi.org/10.1109/WSC.2008.4736057.

Shafer, S. M., \& Charnes, J. M. (1993). Cellular versus functional layouts under a variety of shop operating conditions. Decision Sciences, 24(3), 665-682. http://dx.doi.org/10.1111/j.1540-5915.1993.tb01297.x.

Shafigh, F., Defersha, F. M., \& Moussa, S. E. (2015). A mathematical model for the design of distributed layout by considering production planning and system reconfiguration over multiple time periods. Journal of Industrial Engineering International, 11(3), $283-295$. http://dx.doi.org/10.1007/s40092-015-0102-1.

Sieckmann, F., Ngoc, H. N., Helm, R., \& Kohl, H. (2018). Implementation of lean production systems in small and medium-sized pharmaceutical enterprises. Procedia Manufacturing, 21, 814-821. http://dx.doi.org/10.1016/j.promfg.2018.02.188.

Silva, A. L., \& Rentes, A. F. (2012). A layout design model for job shop environments with high variety of parts based on lean production concepts. Gestão \& Produção, 19(3), 531-541. http://dx.doi.org/10.1590/S0104-530X2012000300007.

Suresh, N. C., \& Slomp, J. (2005). Performance comparison of virtual cellular manufacturing with functional and cellular layouts in DRC settings. International Journal of Production Research, 43(5), 945-979. http://dx.doi.org/10.1080/00207540412331320508.

Thomé, A. M. T., Scavarda, L. F., \& Scavarda, A. J. (2016). Conducting systematic literature review in operations management. Production Planning and Control, 27(5), 408-420. http://dx.doi.org/10.1080/09537287.2015.1129464.

Tranfield, D., Denyer, D., \& Smart, P. (2003). Towards a methodology for developing evidence-informed management knowledge by means of systematic review. British Journal of Management, 14(3), 207-222. http://dx.doi.org/10.1111/1467-8551.00375.

Tranfield, D., Denyer, D., Marcos, J., \& Burr, M. (2004). Co-producing management knowledge. Management Decision, 42(3-4), 375386. http://dx.doi.org/10.1108/00251740410518895.

Wang, G., Shin, Y. W., \& Moon, D. H. (2015). Comparison of three flow line layouts with unreliable machines and profit maximization. Flexible Services and Manufacturing Journal, 28(4), 669-693. http://dx.doi.org/10.1007/s10696-015-9233-3.

Wang, Z., Yang, J., Wang, G., \& Zhang, G. (1987). Computer-Aided Design. Proceedings of the institution of Mechanical Engineers, Part C: Journal of Mechanical Engineering Science, 19(10), 521-571.

Watanapa, A., \& Wiyaratn, W. (2018 March 14-16). Improvement of rubber smoked sheet plant using arena layout for increasing productivity. In Proceedings of the International MultiConference of Engineers and Computer Scientists (Vol. 2). Hong Kong: IMECS.

Zattar, 1. C., Ferreira, J. C. E., Rodrigues, J. G. G. G., \& de Sousa, C. H. B. (2010). A multi-agent system for the integration of process planning and scheduling using operation-based time-extended negotiation protocols. International Journal of Computer Integrated Manufacturing, 23(5), 441-452. http://dx.doi.org/10.1080/09511921003665775. 


\section{ERRATUM}

In the article Assessment of shop floor layouts in the context of process plans with alternatives, D01 number: http://dx.doi.org/10.1590/0103-6513.20180078, published in Production journal, 29: e20180078, page 1:

Where it reads:

"Claudio Decker Decker Junior"

It should read:

"Claudio Decker Junior" 